\title{
Analysis of Supply Chain and Value Chain on Smoked Manyung Fish to Increase Sales on "Asap Indah" Fish Production Center Wonosari Village Demak
}

\author{
Analisis Rantai Pasok dan Rantai Nilai pada Produk Ikan Asap \\ Manyung Dalam Meningkatkan Penjualan di Sentra Pengolahan \\ Ikan “Asap Indah” Desa Wonosari Demak
}

\author{
Niken Siswaningsih ${ }^{1}$, Pramudi Arsiwi ${ }^{1}$, Tita Talitha ${ }^{1}$ \\ ${ }^{1}$ Program Studi Teknik Industri, Fakultas Teknik, Universitas Dian Nuswantoro \\ Jl. Nakula I no. 5-11. Semarang, Jawa Tengah, 50131 \\ Email : pramudi.arsiwi@dsn.dinus.ac.id \\ doi: https://doi.org/10.31315/opsi.v14i2.5339
}

Received: $9^{\text {th }}$ Agustus 2021; Revised: $16^{\text {th }}$ September 2021; Accepted: $25^{\text {th }}$ September 2021; Available online: $21^{\text {st }}$ December 2021; Published regularly: December 2021

\begin{abstract}
Fish Production Center "Asap Indah" is one of the production centers in Demak, which specializes in processing fresh fish into semi-processed products, smoked fish. To support the sustainability of product distribution, supply chain management is needed to oversee the process from procurement of raw material to distribution to final consumers. Therefore, a comprehensive supply chain management analysis is necessary to increase sales and establish effective distribution channels. This research aims to understand the existing value chains of smoked manyung fish, the added value of each contributor on value chains, and to determine the most effective distribution channels of smoked manyung fish. The method used for data processing is descriptive-analytic SCM, Value Chain, and Value Added method. The result of this research, based on value-added calculation analysis using the Hayami method, shows fresh fish wholesalers give the least added value to the product or have the least amount of activities, so decreasing the unproductive activity to lower production cost is recommended. Value chain analysis shows that distribution channels or the most effective selling method of smoked fish are direct selling to the final consumer, accompanied by developing vacuum packaging to increase consumers' interest in the product.
\end{abstract}

Keywords: Smoked Fish; SCM; Value Chain; Value Added

\begin{abstract}
ABSTRAK
Sentra Pengolahan Ikan “Asap Indah” merupakan salah satu sentra di Kota Demak yang melakukan proses produksi pengubahan ikan segar menjadi produk setengah matang berupa ikan asap. Dalam mendukung keberlangsungan berjalannya suatu proses pendistribusian produk maka diperlukan pengelolaan supply chain mulai dari pengadaan bahan baku hingga penyaluran produk yang dihasilkan ke konsumen akhir. Oleh sebab itu, perlunya dilakukan analisis pengelolaan rantai pasok yang diharapkan mampu meningkatkan penjualan dan mengefisiensikan saluran distribusinya. Penelitian ini bertujuan untuk mengetahui rantai nilai ikan asap manyung yang terjadi, penambahan nilai tambah pada masing-masing pelaku rantai nilai dan mengetahui saluran distribusi ikan asap manyung yang paling efisien. Metode yang digunakan dalam pengolahan data adalah metode analisis deskriptif SCM, metode Value Chain dan Value Added. Hasil dari penelitian menunjukkan bahwa berdasarkan analisis perhitungan nilai tambah menggunakan metode Hayami menunjukkan bahwa Tengkulak Ikan Segar memberikan hasil nilai tambah terkecil atau paling sedikit kegiatannya, sehingga perlu dilakukan pengurangan kegiatan yang tidak bernilai tambah agar dapat menurunkan biaya produksi. Selain itu, pada hasil analisis rantai nilai, menunjukkan bahwa saluran pendistribusian atau penjualan ikan asap yang paling efisien adalah penjualan yang tertuju langsung ke konsumen akhir dan perlu diiringi dengan pengembangan kemasan vacum agar menambah daya tarik pembeli.
\end{abstract}

Kata Kunci: Ikan Asap; SCM; Value Chain; Value Added 


\section{PENDAHULUAN}

Sentra Pengolahan Ikan "Asap Indah" memproduksi salah satu olahan makanan yang pengolahannya dengan proses pengawetan tanpa bahan pegawet berbahaya, melainkan dengan menggunakan metode pengasapan. Sehingga mampu menghasilkan aroma yang sedap dan khas. Dalam memenuhi kebutuhan bahan baku produksi, para pemilik usaha mendapatkannya dari berbagai daerah, salah satunya adalah Juwana. Yang selanjutnya adalah diambil oleh para Tengkulak Ikan Segar yang kemudian dijual ke para pelaku usaha Pengolah Ikan Asap di Sentra Pengolahan Ikan "Asap Indah" untuk dilakukannya pengolahan ataupun proses produksi ikan asap hingga mereka jual langsung ke konsumen maupun dijual melalui Pengecer Ikan Asap atau melalui pelaku usaha Warung Makan terlebih dahulu sebelum dipasarkan lagi ke konsumen. Berdasarkan hasil observasi dan wawancara dengan Bapak Tejo Purwoto selaku Ketua Sentra Pengolahan Ikan "Asap Indah" menyebutkan bahwa permintaan ikan asap perharinya cukup tinggi dengan rata-rata 20-25 ton. Selain itu, dengan melibatkannya banyak pelaku yang terlibat sehingga membuat rantai pasoknya menjadi panjang, kemudian akan terjadi perbedaan harga jual ikan dan terlihat perbedaan yang cukup mencolok terkait margin profit antar pelaku serta profit margin yang diperoleh oleh Pengolah Ikan Asap sangat kecil. Sehingga perlunya dilakukan pengelolaan supply chain pada olahan ikan asap karena memiliki peranan penting dimulai dari penyediaan bahan baku hingga ikan dapat dikonsumsi oleh konsumen.

Penelitian terkait supply chain dan value chain telah dilakukan beberapa peneliti sebelumnya diantaranya penelitian mengenai upaya peningkatan nilai produk ikan asap Bandarharjo Kota Semarang dengan menggunakan analisis value chain (Arsiwi, Adi, \& Subhiyakto, 2018). Penelitian terkait pengurangan waktu proses pelayanan dengan merancang sistem proses bisnis pada bank sampah Resik Besik Becik berbasis teknologi yang mana value chain digunakan untuk mengetahui nilai dari tiap pelaku jeringan dan melakukan perbaikan pada mata rantai yang kurang efektif (Estiningtyas, 2020). Penelitian mengenai penentuan nilai tambah pada produk olahan makanan dari kulit sapi dengan menggunakan strategi rantai pasok (Hariadi et al., 2019). Penelitian pada produk kopi guna meningkatkan keunggulan bersaing sehingga diperoleh aktivitas rantai nilai yang memiliki skor tinggi adalah kegiatan logistik ke dalam (Ishaq, Rumiati, \& Permatasari, 2017). Penelitian pada jeruk pamelo dengan menggunakan analisis supply chain dan value chain yang mana olahan jeruk pamelo di suatu rumah industri memiliki nilai tambah yang lebih tinggi (Nurfadilah, 2017). Penelitian pada rantai pasok kentang dengan melakukan pemotongan salah satu pelaku yang terlibat yaitu pengepul dengan mengganti koperasi pertanian, hal tersbut dapat meningkatkan pendapatan petani kentang (Irawati, 2021). Penelitian terkait rantai pasok dan nilai tambah pada komoditas carica dan menunjukkan hasil bahwa pengolahan carica menjadi manisan memberikan keuntungan (Azizi, 2018). Pengkajian mengenai efisiensi pemasaran kentang menggunakan analisis deskriptif managemen rantai pasok (Nurhuda, 2017). Penerapan analisis non value added activity menggunakan penerapan activity based management untuk meningkatkan efisiensi dengan hasil menunjukkan biaya yang dikeluarkan berkurang sebesar 20\% (Kutika, 2018).

Berdasarkan permasalahan yang telah diuraikan dan didukung beberapa penelitian peneliti sebelumnya, maka pada penelitian ini diharapkan mampu menganalisis rantai nilai ikan asap manyung di Sentra "Asap Indah", mengetahui dan menganalisis penambahan nilai tambah yang diberikan setiap pelaku rantai nilai ikan asap manyung di Sentra "Asap Indah", dan mampu mengetahui dan menganalisis saluran distribusi ikan asap manyung di Sentra "Asap Indah" yang paling efisien.

\section{METODE}

Jenis penelitian yang digunakan dalam penelitian ini adalah deskriptif kualitatif. Penelitian dilaksanakan pada bulan Desember 2020 hingga bulan Juni 2021 di Sentra Pengolahan Ikan "Asap Indah" Desa Wonosari Demak.

Pengumpulan data dilakukan dengan cara wawancara, pengisian kuesioner, dokumentasi, dan menggali informasi mengenai jumlah produksi ikan asap manyung dan juga saluran distribusi dari ikan asap manyung. Responden 
dari penelitian ini merupakan pihak yang terlibat dalam aliran rantai pasok ikan asap manyung.

Setelah data-data yang dibutuhkan terkumpul, selanjutnya adalah dilakukannya pengolahan data dengan tiga metode. Metode pertama adalah menganalisis SCM dengan melakukan penggambaran aliran supply chain ikan asap manyung mulai dari pemasok ikan segar hingga konsumen akhir dari ikan asap kemudian menganalisis aliran yang terjadi baik aliran material, keuangan dan informasi. Metode yang kedua adalah value chain yang dapat dikerjakan dengan menggunakan dua cara yaitu secara kuantitatif dan kualitatif. Metode yang ketiga adalah perhitungan value added dengan menggunakan metode hayami. Selanjutnya dilakukan tahapan analisis dan pembahasan dari hasil pengolahan data dan diperoleh kesimpulan dan saran penelitian. Gambar 1 merupakan flowchart penelitian yang dilakukan.

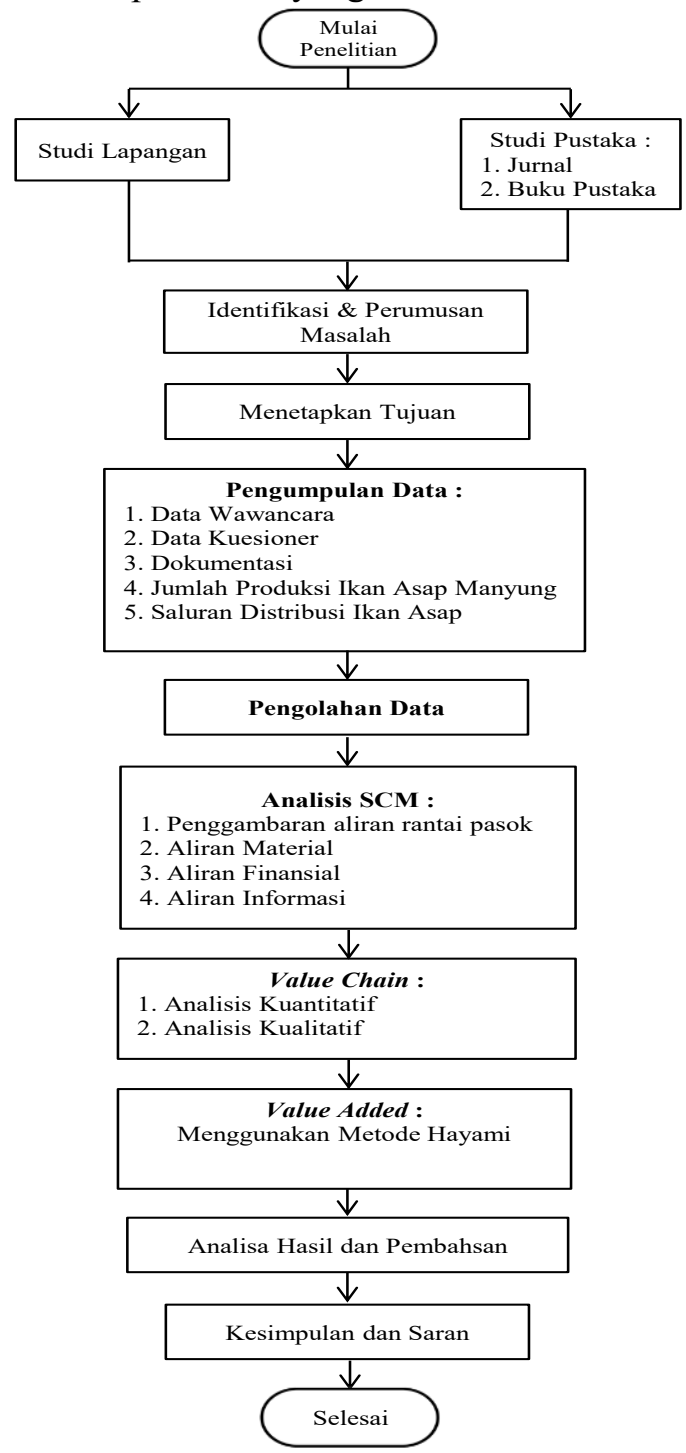

Gambar 1. Flowchart Penelitian

\section{HASIL DAN PEMBAHASAN}

\subsection{Jumlah Responden}

Responden pada penelitian ini keseluruhannya berjumlah sebanyak 27 orang responden, yang mana merupakan pihak yang terlibat dalam aliran rantai pasok ikan asap manyung di Sentra Pengolahan Ikan "Asap Indah". Tabel 1 menunjukkan karakteristik dan jumlah responden dalam penelitian ini.

Tabel 1. Jumlah Responden

\begin{tabular}{clr}
\hline No. & Objek & Jumlah \\
\hline 1 & TPI Unit 1 Juwana & 1 \\
2 & Gudang Ikan & 1 \\
3 & Tengkulak & 1 \\
4 & Sentra Pengolahan Ikan “Asap & 11 \\
& Indah” & 11 \\
5 & Pengecer & 2 \\
6 & Warung Makan & 27 \\
Jumlah
\end{tabular}

\subsection{Analisis Rantai Pasok}

Berdasarkan data yang diperoleh, bahwa aliran distribusi ikan manyung di Sentra Pengolahan Ikan "Asaap Indah" melibatkan pelaku usaha mulai dari pemasok ikan segar manyung hingga konsumen akhir dari ikan manyung. Dalam kegiatan yang berlangsung, pastinya akan melibatkan tiga macam aliran yang terjadi yaitu aliran material, keuangan dan informasi. Gambar 2 merupakan aliran rantai pasok dari produk ikan asap manyung dan berdasarkan Gambar 2 terdapat empat saluran yang terjadi.

Pada aliran material atau barang, menunjukkan bahwa terjadinya arus perpindahan barang berupa produk fisik (Nurfadilah, 2017) dari satu tempat menuju tempat lain yang alirannya dimulai dari hulu yang merupakan pemasok awal ikan segar dan kemudian menuju hilir yang merupakan konsumen akhir dari produk ikan asap manyung. Terdapat dua penyuplai ikan manyung segar yaitu TPI Unit 1 dan Gudang Ikan yang berada di Juwana. Keduanya dialirkan menuju Sentra Pengolahan Ikan "Asap Indah" melalui pedagang perantara yakni Tengkulak Ikan Segar. Setibanya ikan segar yang dibawa Tengkulak Ikan Segar di Sentra Pengolahan Ikan "Asap Indah", selanjutnya dilakukan pengolahan atau proses produksi pengubahan menjadi produk ikan asap 


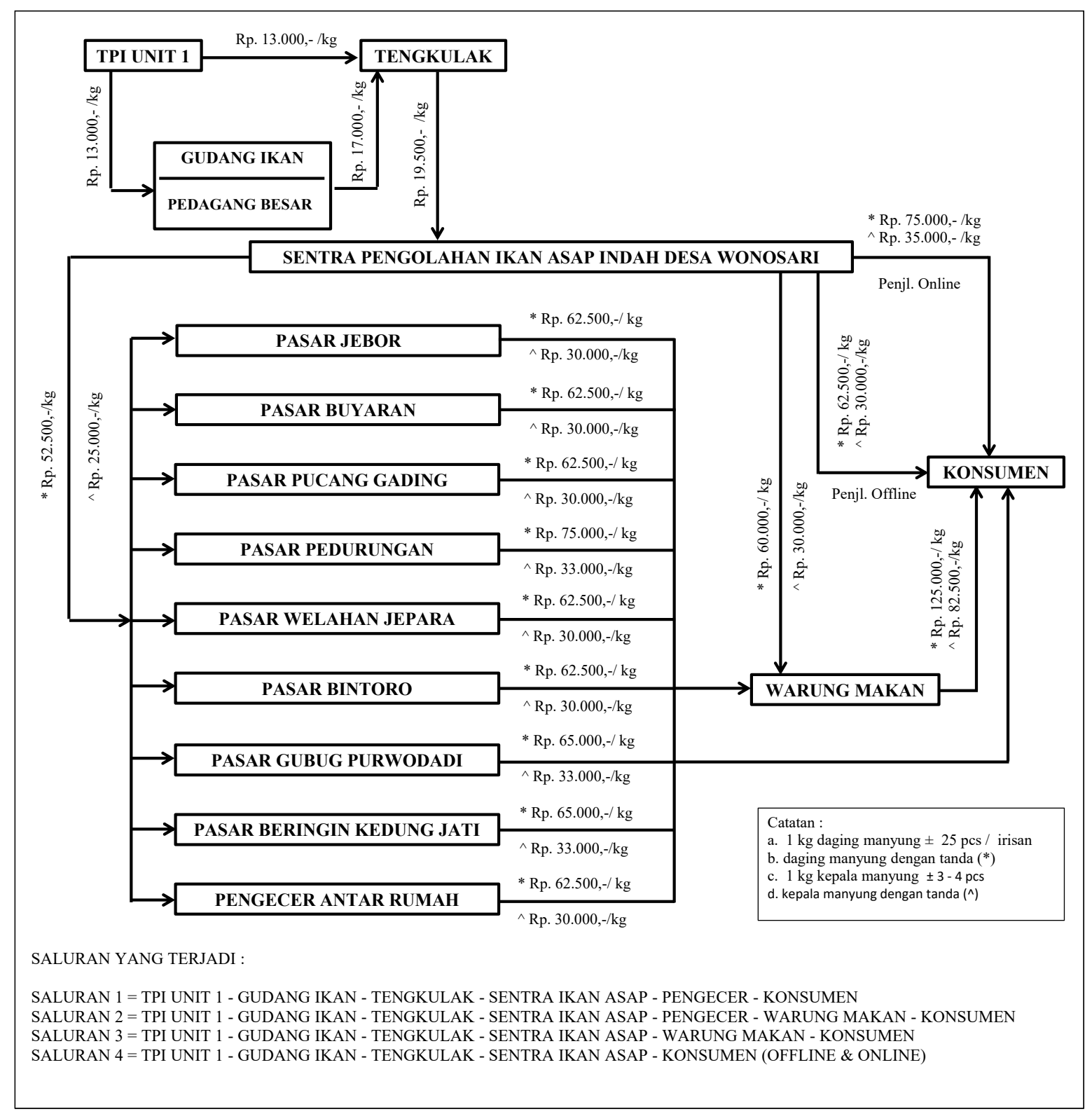

Gambar 2. Aliran Rantai Pasok Dari Produk Ikan Asap Manyung

oleh para Pengolah Ikan Asap menggunakan bahan bakar utama berupa janggel jagung maupun batok kepala. Berdasarkan hasil wawancara dengan Bapak Tejo Purwoto selaku Ketua Sentra Pengolahan Ikan "Asap Indah", beliau menyebutkan bahwa dalam 1 kwintal ikan manyung setelah dilakukannya proses pengolahan dan pengasapan terjadi proses penyusutan berat sebesar 20-30\%. Setelah proses pengasapan selesai, aliran selanjutnya masuk ke proses penjualan, dimana dari para pelaku usaha di Sentra Pengolahan Ikan "Asap Indah" dapat memasarkan langsung ke konsumen akhir, pelaku usaha warung makan maupun melalui Pengecer Ikan Asap. Dalam 1 kg kepala manyung biasaya berisi kurang lebih 3 pcs dan dalam $1 \mathrm{~kg}$ daging manyung biasanya berisi kurang lebih 25 pcs atau irisan. Dari Pengecer ikan asap kemudian dilakukan penjualan lagi baik pelaku usaha warung makan maupun konsumen biasa. Selain itu, pendistribusian ikan asap juga dilakukan melalui pelaku usaha dibidang Warung Makan, yang mana mereka melakukan pengolahan kembali produk setengah matang dari ikan asap menjadi produk siap makan dan dikonsumsi langsung oleh konsumen.

Aliran keuangan yang terjadi memberikan gambaran bahwa terjadinya proses perpindahan sejumlah uang yang berpindah dari konsumen (hilir) hingga berakhir di produsen akhir (hulu) 
sebagai bentuk alat tukar dengan apa yang telah diperoleh dan didapatkan. Harga dari ikan manyung di pemasok awal yaitu TPI Unit 1 berkisar Rp. 13.000,-/kg dan berbeda di Gudang Ikan dikarenakan adanya faktor penambahan nilai pada ikan manyung seharga Rp. 17.000,-/kg. Kemudian baik dari TPI Unit 1 maupun Gudang Ikan kemudian dibeli oleh Tengkulak sebagai pedagang perantara dengan dan dijual kembali seharga Rp. 19.500,-/kg. Setelah ikan selesai dilakukan pengolahan menjadi produk setengah matang, selanjutnya ikan asap dijual ke para pengecer dengan harga Rp. $25.000,-/ \mathrm{kg}$ untuk kepala ikan manyung dan Rp. 52.500,-/kg untuk daging ikan manyung. Untuk harga jual ke konsumen akhir, harga $1 \mathrm{~kg}$ kepala Manyung sebesar Rp. 30.000,- dan untuk $1 \mathrm{~kg}$ daging manyung sebesar Rp. 62.500,-, sedangkan penjualan ke Warung Makan untuk harga $1 \mathrm{~kg}$ kepala manyung sebesar Rp. 30.000,- dan untuk $1 \mathrm{~kg}$ daging manyung sebesar Rp. 60.000,-. Dari Pengecer Ikan Asap tersebut, menjual kepala manyung rata-rata $1 \mathrm{~kg}$ sebesar Rp. 31.000,- dan daging manyung rata-rata $1 \mathrm{~kg}$ sebesar $\mathrm{Rp}$. 64.500,-. Selain itu, pendistribusian atau penjualan dari ikan asap yang dilakukan melalui pelaku usaha Warung Makan, mereka menjual 1 $\mathrm{kg}$ kepala manyung rata-rata dengan harga $\mathrm{Rp}$. 82.500 ,- dan untuk $1 \mathrm{~kg}$ daging manyung mampu dijual dengan rata-rata harga Rp. 125.000,-.

Sedangkan pada aliran informasi terjadi dari dua arah, baik hulu menuju hilir atau sebaliknya hilir menuju hulu yang digunakan untuk mengetahui seberapa efektif rantai pasok yang berjalan dalam jangka waktu yang lama dan akan berkaitan untuk melakukan perbaikan pada suatu produk yang masih dirasa masih kurang dan perlu perbaikan (Nurhuda, 2017). Hal ini selaras dengan penelitian yang dilakukan oleh Arsiwi, dkk (2018) pada produk ikan asap Bandarharjo Kota Semarang yang mana aliran informasi yang terjadi meliputi jumlah permintaan, jumlah persediaan, harga produk dimasing-masing pelaku dan informasi mengenai kriteria produk yang diharapkan (Arsiwi et al., 2018). Pada pelaku pemasok ikan segar ke pelaku Pengolah Ikan Asap yaitu TPI Unit 1, Gudang Ikan maupun Tengkulak Ikan Segar, aliran informasi yang diperoleh adalah berupa jumlah persediaan yang diperoleh, permintaan dari ikan segar yang akan dibeli dan terkait dengan harga jual ikan manyung segar. Sedangkan aliran balik informasi dari Pengolah Ikan Asap ke Pemasok Ikan Segar adalah mengenai jumlah perkiraan ikan asap yang terjual per harinya yang akan dijadikan sebagai acuan dalam memperkirakan jumlah ikan segar yang dibutuhkan Pengolah Ikan Asap pada Pemasok Ikan Segar tersebut. Selanjutnya aliran informasi yang terjadi dari Pengolah Ikan Asap ke Pengecer Ikan Asap, Warung Makan maupun konsumen yang membeli langsung di Sentra Pengolahan Ikan "Asap Indah" diantaranya kapasitas atau jumlah ikan asap yang mampu diproduksi dalam sehari, harga jual dari ikan asap per kilogram baik kepala manyung maupun daging manyung dan terkait dengan waktu pengambilan ikan asap setelah proses produksi yang dilakukan selesai. Kemudian aliran balik informasi yang terjadi baik dari Pengecer Ikan Asap maupun Warung Makan ke Pengolah Ikan Asap yaitu mengenai jumlah produk yang mampu terjual dalam sehari ke konsumen.

\subsection{Analisis Rantai Nilai (Value Chain)}

Menurut Nurfadilah (2017) analisis value chain dapat dikerjakan dengan menggunakan 2 cara yaitu analisis secara kuantitatif dan analisis secara kualitatif (Nurfadilah, 2017).

\section{A. Analisis Kuantitatif \\ 1. Perhitungan Biaya yang Dikeluarkan}

Perhitungan biaya yang dikeluarkan oleh masing-masing pelaku usaha diperoleh dari hasil penjumlahan biaya tetap dan biaya variabel yang dikeluarkan. Tabel 2 merupakan biaya pengeluaran tiap pelaku rantai nilai.

\section{Perhitungan Penerimaan}

Perhitungan penerimaan pelaku rantai pasok diperoleh dari hasil perkalian berdasarkan hasil produksi yang diperoleh kemudian dikali dengan harga jual dari produk (Irawati, 2021). Tabel 3 merupakan tabel perhitungan penerimaan yang diperoleh masing-masing pelaku rantai ikan asap manyung.

\section{Perhitungan Pendapatan}

Perhitungan pendapatan pelaku rantai nilai yang diperoleh berdasarkan hasil selisih dari penerimaan dengan biaya yang dikeluarkan oleh masing-masing pelaku usaha dalam rantai nilai (Irawati, 2021). Tabel 4 merupakan tabel perhitungan pendapatan yang diperoleh dari masing-masing pelaku rantai nilai ikan manyung. 
Tabel 2. Biaya Pengeluaran Tiap Pelaku Rantai Nilai

\begin{tabular}{rcrrrrrr}
\hline \multirow{2}{*}{ No. } & \multirow{2}{*}{ Pelaku Rantai Nilai } & \multicolumn{2}{c}{ TFC = Jumlah } & \multicolumn{2}{c}{ TVC = Jumlah } & \multicolumn{2}{c}{ TC = Perhitungan Biaya } \\
\cline { 3 - 7 } & & \multicolumn{2}{c}{ Biaya Tetap } & \multicolumn{2}{c}{ Biaya Variabel } & \multicolumn{2}{c}{ yang Dikeluarkan } \\
\hline 1 & TPI Unit 1 & $\mathrm{Rp}$ & 31.987 .500 & $\mathrm{Rp}$ & 6.536 .250 & $\mathrm{Rp}$ & 38.523 .750 \\
2 & Gudang Ikan & $\mathrm{Rp}$ & 131.350 .000 & $\mathrm{Rp}$ & 12.400 .000 & $\mathrm{Rp}$ & 143.750 .000 \\
3 & Tengkulak Ikan Segar & $\mathrm{Rp}$ & 68.700 .000 & $\mathrm{Rp}$ & - & $\mathrm{Rp}$ & 68.700 .000 \\
4 & Pengolah Ikan Asap & $\mathrm{Rp}$ & 6.373 .823 & $\mathrm{Rp}$ & 183.000 & $\mathrm{Rp}$ & 6.556 .823 \\
5 & Pengecer Ikan Asap & $\mathrm{Rp}$ & 692.076 & $\mathrm{Rp}$ & 31.000 & $\mathrm{Rp}$ & 723.076 \\
6 & Warung Makan & $\mathrm{Rp}$ & 1.044 .286 & $\mathrm{Rp}$ & 152.000 & $\mathrm{Rp}$ & 1.196 .286 \\
\hline
\end{tabular}

Tabel 3. Perhitungan Penerimaan Tiap Pelaku Rantai Nilai

\begin{tabular}{|c|c|c|c|c|c|c|}
\hline \multirow{2}{*}{ No. } & \multirow{2}{*}{ Pelaku Rantai Nilai } & $\mathrm{Q}=$ Jumlah Produk & \multicolumn{2}{|c|}{$\mathrm{P}=$ Harga Jual Produksi } & \multicolumn{2}{|c|}{$\mathrm{TR}=$ Perhitungan } \\
\hline & & Ikan Manyung (Kg.) & \multicolumn{2}{|c|}{ Ikan Manyung (Rp.) } & \multicolumn{2}{|c|}{ Penerimaan produksi (Rp.) } \\
\hline 1 & TPI Unit 1 & 15000 & $\mathrm{Rp}$ & 13.000 & $\mathbf{R p}$ & 195.000 .000 \\
\hline 2 & Gudang Ikan & 10000 & $\mathrm{Rp}$ & 17.000 & $\mathbf{R p}$ & 170.000.000 \\
\hline \multirow{10}{*}{$\begin{array}{l}3 \\
4\end{array}$} & Tengkulak Ikan Segar & 4000 & $\mathrm{Rp}$ & 19.500 & $\mathbf{R p}$ & 78.000.000 \\
\hline & \multicolumn{6}{|l|}{ Pengolah Ikan Asap } \\
\hline & \multicolumn{6}{|l|}{ Kepala Manyung } \\
\hline & Pengecer Ikan Asap & 100 & $\mathrm{Rp}$ & 25.000 & $\mathrm{Rp}$ & 2.500 .000 \\
\hline & Warung Makan & 36 & $\mathrm{Rp}$ & 30.000 & $\mathrm{Rp}$ & 1.080 .000 \\
\hline & Konsumen & 2 & $\mathrm{Rp}$ & 30.000 & $\mathrm{Rp}$ & 60.000 \\
\hline & \multicolumn{6}{|l|}{ Daging Manyung } \\
\hline & Pengecer Ikan Asap & 94 & $\mathrm{Rp}$ & 52.500 & $\mathrm{Rp}$ & 4.935 .000 \\
\hline & Warung Makan & 1 & $\mathrm{Rp}$ & 60.000 & $\mathrm{Rp}$ & 60.000 \\
\hline & Konsumen & 1 & $\mathrm{Rp}$ & 62.500 & $\mathrm{Rp}$ & 62.500 \\
\hline \multicolumn{5}{|c|}{ Total Perhitungan Penerimaan Produksi Pengolah Ikan Asap } & $\mathbf{R p}$ & 8.697.500 \\
\hline J & Pengecer Ikan Asap & & & & & \\
\hline & Kepala Manyung & 9 & $\mathrm{Rp}$ & 31.000 & $\mathrm{Rp}$ & 281.818 \\
\hline & Daging Manyung & 9 & $\mathrm{Rp}$ & 64.444 & $\mathrm{Rp}$ & 550.707 \\
\hline \multicolumn{5}{|c|}{ Total Perhitungan Penerimaan Produksi Pengecer Ikan Asap } & $\mathbf{R p}$ & 832.525 \\
\hline 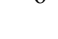 & \multicolumn{6}{|l|}{ Warung Makan } \\
\hline & Kepala Manyung & 18 & $\mathrm{Rp}$ & 82.500 & $\mathrm{Rp}$ & 1.485 .000 \\
\hline & Daging Manyung & 1 & $\mathrm{Rp}$ & 125.000 & $\mathrm{Rp}$ & 125.000 \\
\hline \multicolumn{5}{|c|}{ Total Perhitungan Penerimaan Produksi Warung Makan Ikan Asap } & $\mathbf{R p}$ & 1.610 .000 \\
\hline
\end{tabular}

Tabel 4. Perhitungan Pendapatan Tiap Pelaku Rantai Nilai

\begin{tabular}{|c|c|c|c|c|c|c|c|}
\hline \multirow{2}{*}{ No. } & \multirow{2}{*}{ Pelaku Rantai Nilai } & \multicolumn{2}{|c|}{$\mathrm{TR}=$ Total Penerimaan } & \multicolumn{2}{|c|}{$\mathrm{TC}=$ Total Biaya } & \multicolumn{2}{|c|}{ Pendapatan Tiap } \\
\hline & & \multicolumn{2}{|c|}{ Produksi (Rp.) } & \multicolumn{2}{|c|}{ Produksi (Rp.) } & \multicolumn{2}{|c|}{ Pelaku (Rp.) } \\
\hline 1 & TPI Unit 1 & $\mathrm{Rp}$ & 195.000 .000 & $\mathrm{Rp}$ & 38.523 .750 & $\mathrm{Rp}$ & 156.476 .250 \\
\hline 2 & Gudang Ikan & $\mathrm{Rp}$ & 170.000 .000 & $\mathrm{Rp}$ & 143.750 .000 & $\mathrm{Rp}$ & 26.250 .000 \\
\hline 3 & Tengkulak Ikan Segar & $\mathrm{Rp}$ & 78.000 .000 & $\mathrm{Rp}$ & 68.700 .000 & $\mathrm{Rp}$ & 9.300 .000 \\
\hline 4 & Pengolah Ikan Asap & $\mathrm{Rp}$ & 8.697 .500 & $\mathrm{Rp}$ & 6.556 .823 & $\mathrm{Rp}$ & 2.140 .677 \\
\hline 5 & Pengecer Ikan Asap & $\mathrm{Rp}$ & 832.525 & $\mathrm{Rp}$ & 723.076 & $\mathrm{Rp}$ & 109.449 \\
\hline 6 & Warung Makan & $\mathrm{Rp}$ & 1.610 .000 & $\mathrm{Rp}$ & 1.196 .286 & $\mathrm{Rp}$ & 413.714 \\
\hline
\end{tabular}


Tabel 5. Perhitungan Margin Pemasaran Tiap Pelaku Rantai Nilai

\begin{tabular}{|c|c|c|c|c|c|c|c|}
\hline \multirow{3}{*}{$\begin{array}{r}\text { No. } \\
1\end{array}$} & \multirow{3}{*}{$\begin{array}{l}\text { Pelaku Rantai Nilai } \\
\text { TPI Unit } 1\end{array}$} & \multirow{2}{*}{\multicolumn{2}{|c|}{$\begin{array}{l}\text { Pri }=\text { Harga ditingkat } \\
\text { tertentu (Rp.) }\end{array}$}} & \multirow{2}{*}{\multicolumn{2}{|c|}{$\begin{array}{l}\text { Pfi }=\text { Harga ditingkat } \\
\text { berikutnya }(\mathrm{Rp} .)\end{array}$}} & \multirow{2}{*}{\multicolumn{2}{|c|}{$\frac{\text { Mji }=\text { Margin Pemasaran pada }}{\text { Tingkat Lembaga ke } 1 \text { (Rp.) }}$}} \\
\hline & & & & & & & \\
\hline & & $\mathrm{Rp}$ & 13.000 & $\mathrm{Rp}$ & 2.571 & $\mathrm{Rp}$ & 10.429 \\
\hline 2 & Gudang Ikan & $\mathrm{Rp}$ & 17.000 & $\mathrm{Rp}$ & 13.000 & $\mathrm{Rp}$ & 4.000 \\
\hline \multirow{10}{*}{$\begin{array}{l}3 \\
4\end{array}$} & Tengkulak Ikan Segar & $\mathrm{Rp}$ & 19.500 & $\mathrm{Rp}$ & 17.000 & $\mathrm{Rp}$ & 2.500 \\
\hline & Pengolah Ikan Asap & & & & & & \\
\hline & Kepala Manyung & & & & & & \\
\hline & Pengecer Ikan Asap & $\mathrm{Rp}$ & 25.000 & $\mathrm{Rp}$ & 19.500 & $\mathrm{Rp}$ & 5.500 \\
\hline & Warung Makan & $\mathrm{Rp}$ & 30.000 & $\mathrm{Rp}$ & 19.500 & $\mathrm{Rp}$ & 10.500 \\
\hline & Konsumen & $\mathrm{Rp}$ & 30.000 & $\mathrm{Rp}$ & 19.500 & $\mathrm{Rp}$ & 10.500 \\
\hline & Daging Manyung & & & & & & \\
\hline & Pengecer Ikan Asap & $\mathrm{Rp}$ & 52.500 & $\mathrm{Rp}$ & 19.500 & $\mathrm{Rp}$ & 33.000 \\
\hline & Warung Makan & $\mathrm{Rp}$ & 60.000 & $\mathrm{Rp}$ & 19.500 & $\mathrm{Rp}$ & 40.500 \\
\hline & Konsumen & $\mathrm{Rp}$ & 62.500 & $\mathrm{Rp}$ & 19.500 & $\mathrm{Rp}$ & 43.000 \\
\hline \multirow{3}{*}{5} & Pengecer Ikan Asap & & & & & & \\
\hline & Kepala Manyung & $\mathrm{Rp}$ & 31.000 & $\mathrm{Rp}$ & 25.000 & $\mathrm{Rp}$ & 6.000 \\
\hline & Daging Manyung & $\mathrm{Rp}$ & 64.444 & $\mathrm{Rp}$ & 52.500 & $\mathrm{Rp}$ & 11.944 \\
\hline \multirow{7}{*}{6} & Warung Makan & & & & & & \\
\hline & Pembelian dari Sentra & ngolal & "Asap In & & & & \\
\hline & Kepala Manyung & $\mathrm{Rp}$ & 82.500 & $\mathrm{Rp}$ & 30.000 & $\mathrm{Rp}$ & 52.500 \\
\hline & Daging Manyung & $\mathrm{Rp}$ & 125.000 & $\mathrm{Rp}$ & 60.000 & $\mathrm{Rp}$ & 65.000 \\
\hline & Pembelian dari Pengec & Ikan & & & & & \\
\hline & Kepala Manyung & $\mathrm{Rp}$ & 82.500 & $\mathrm{Rp}$ & 31.000 & $\mathrm{Rp}$ & 51.500 \\
\hline & Daging Manyung & $\mathrm{Rp}$ & 125.000 & $\mathrm{Rp}$ & 64.444 & $\mathrm{Rp}$ & 60.556 \\
\hline \multicolumn{2}{|c|}{ Total Margin Pemasaran } & & & & & $\mathrm{Rp}$ & 407.429 \\
\hline
\end{tabular}

\section{Margin Pemasaran dan Farmers Share}

Margin pemasaran merupakan selisih harga dari tingkat produsen dengan harga ditingkat pedagang tertentu (Irawati, 2021). Tabel 5 merupakan hasil perhitungan margin pemasaran dari masing-masing tiap pelaku rantai nilai.

Tabel 6 merupakan tabel perhitungan Rasio Margin Pemasaran dan perhitungan Farmers Share yang mana digunakan untuk menentukan efisiensi rantai nilai berdasarkan margin terendah hasil dari Pengolah Ikan Asap ke konsumen (Azizi, 2018). Farmers share disini merupakan bagian yang diterima oleh Pengolah Ikan Asap. Perhitungan hasil farmers share dari tiap saluran dapat diperoleh dari hasil bagi antara harga jual ditingkat pengolah dibagi dengan harga ditingkat konsumen akhir.

Berdasarkan tabel 6 , didapatkan 8 saluran pemasaran yang mana saluran tersebut terdiri dari 4 saluran pemasaran kepala ikan manyung dan 4 saluran pemasaran daging manyung. Kedua saluran ke-4 baik pemasaran kepala manyung maupun daging manyung merupakan saluran yang paling efisien dan dapat dikembangkan dengan total margin sebesar Rp. 27.429,- untuk pemasaran kepala manyung dengan farmers share sebesar $100 \%$ dan untuk pemasaran daging manyung total margin sebesar Rp. 59.929,dengan farmers share sebesar $100 \%$.

\section{Perhitungan $R / C$ Ratio}

Pada perhitungan R/C Ratio dilakukan untuk menentukan tingkat efisiensi masing-masing pelaku usaha dalam rantai nilai yang diperoleh dari hasil pembagian jumlah biaya penerimaan dengan jumlah biaya yang dikeluarkan. Tabel 7 merupakan tabel perhitungan $\mathrm{R} / \mathrm{C}$ Ratio tiap pelaku rantai nilai.

Berdasarkan tabel 7, secara keseluruhan pelaku usaha telah memperoleh R/C Ratio $>1$ yang berarti usaha yang dijalankan dapat dikatakan sudah efisien dan menguntungkan. 
Tabel 6. Rasio Margin Pemasaran dan Farmes Share

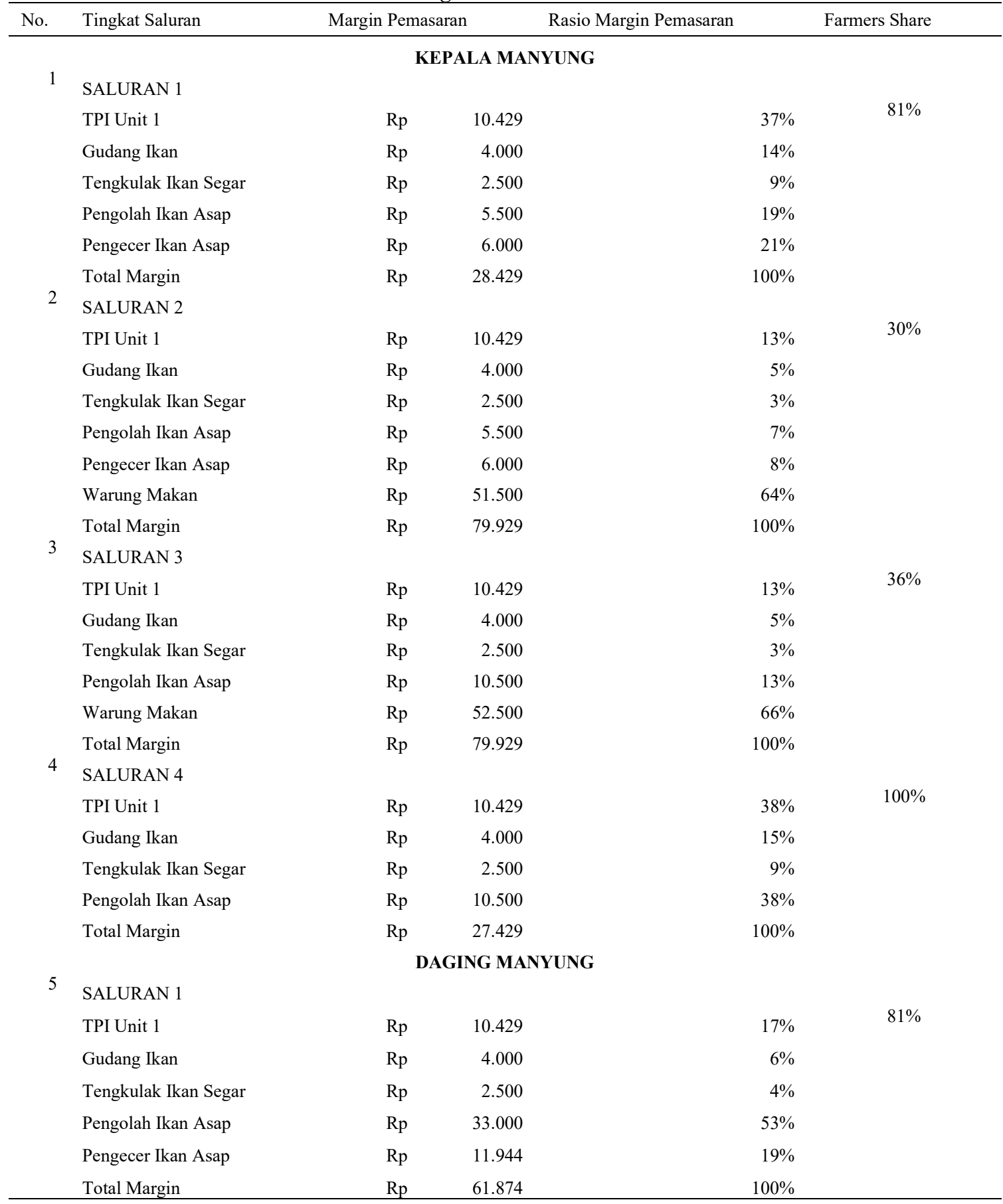

Tabel 7. Perhitungan R/C Ratio

\begin{tabular}{|c|c|c|c|c|c|c|}
\hline \multirow{2}{*}{$\begin{array}{r}\text { No. } \\
1\end{array}$} & \multirow{2}{*}{$\begin{array}{l}\text { Pelaku Rantai Nilai } \\
\text { TPI Unit } 1\end{array}$} & \multicolumn{2}{|c|}{ TR = Jumlah Penerimaan (Rp.) } & \multicolumn{2}{|c|}{ TC = Jumlah Biaya (Rp.) } & \multirow{2}{*}{$\begin{array}{r}\text { R/C Ratio } \\
5,1\end{array}$} \\
\hline & & $\mathrm{Rp}$ & 195.000 .000 & $\mathrm{Rp}$ & 38.523 .750 & \\
\hline 2 & Gudang Ikan & $\mathrm{Rp}$ & 170.000 .000 & $\mathrm{Rp}$ & 143.750 .000 & 1,2 \\
\hline 3 & Tengkulak Ikan Segar & $\mathrm{Rp}$ & 78.000 .000 & $\mathrm{Rp}$ & 68.700 .000 & 1,1 \\
\hline 4 & Pengolah Ikan Asap & $\mathrm{Rp}$ & 8.697 .500 & $\mathrm{Rp}$ & 6.556 .823 & 1,3 \\
\hline 5 & Pengecer Ikan Asap & $\mathrm{Rp}$ & 832.525 & $\mathrm{Rp}$ & 723.076 & 1,2 \\
\hline 6 & Warung Makan & $\mathrm{Rp}$ & 1.610 .000 & $\mathrm{Rp}$ & 1.196 .286 & 1,3 \\
\hline
\end{tabular}




\section{B. Analisis Kualitatif}

Menurut Porter (1985) dalam Mangifera (2015), dijelaskan bahwa aktivitas nilai terbagi menjadi lima bagian, diantaranya adalah aktivitas utama atau primary activities dan empat aktivitas lainnya merupakan aktivitas pendukung atau support activities (Yani \& Pos, 2015).

1. TPI Unit 1 Juwana

Gambar 3 merupakan gambaran model aktivitas rantai nilai menurut Porter (1985) pada pelaku usaha di TPI Unit 1 Juwana.

\section{Gudang Ikan}

Gambar 4 merupakan gambaran model aktivitas rantai nilai menurut Porter (1985) pada pelaku usaha di Gudang Ikan.

\section{Tengkulak Ikan Segar}

Gambar 5 merupakan gambaran model aktivitas rantai nilai menurut Porter (1985) pada pelaku usaha di Tengkulak Ikan Segar.

\section{Pengolah Ikan Asap}

Gambar 6 merupakan gambaran model aktivitas rantai nilai menurut Porter (1985) pada pelaku usaha di Pengolah Ikan Asap.

\section{Pengecer Ikan Asap}

Gambar 7 merupakan gambaran model aktivitas rantai nilai menurut Porter (1985) pada pelaku usaha di Pengecer Ikan Asap.

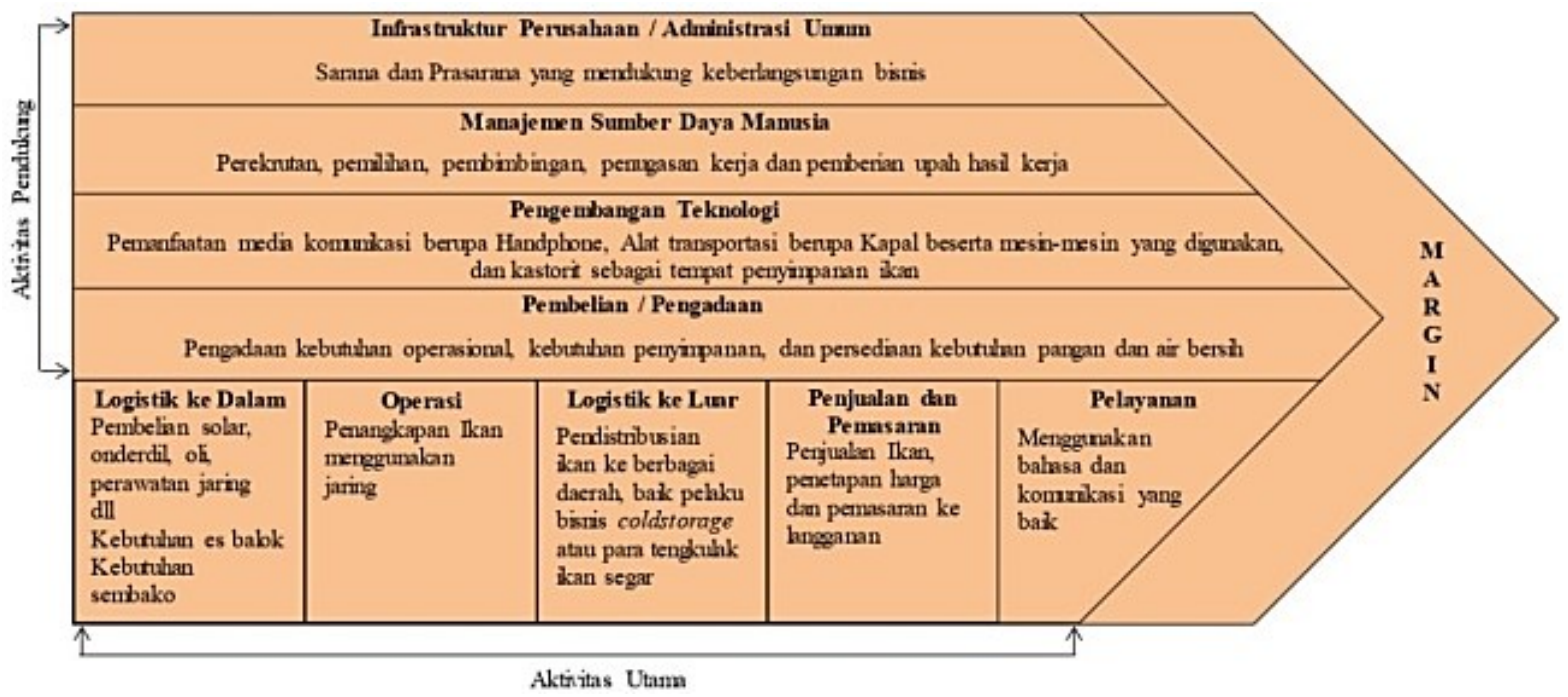

Gambar 3. Aktivitas Rantai Nilai TPI Unit 1 Juwana menurut Porter (1985)

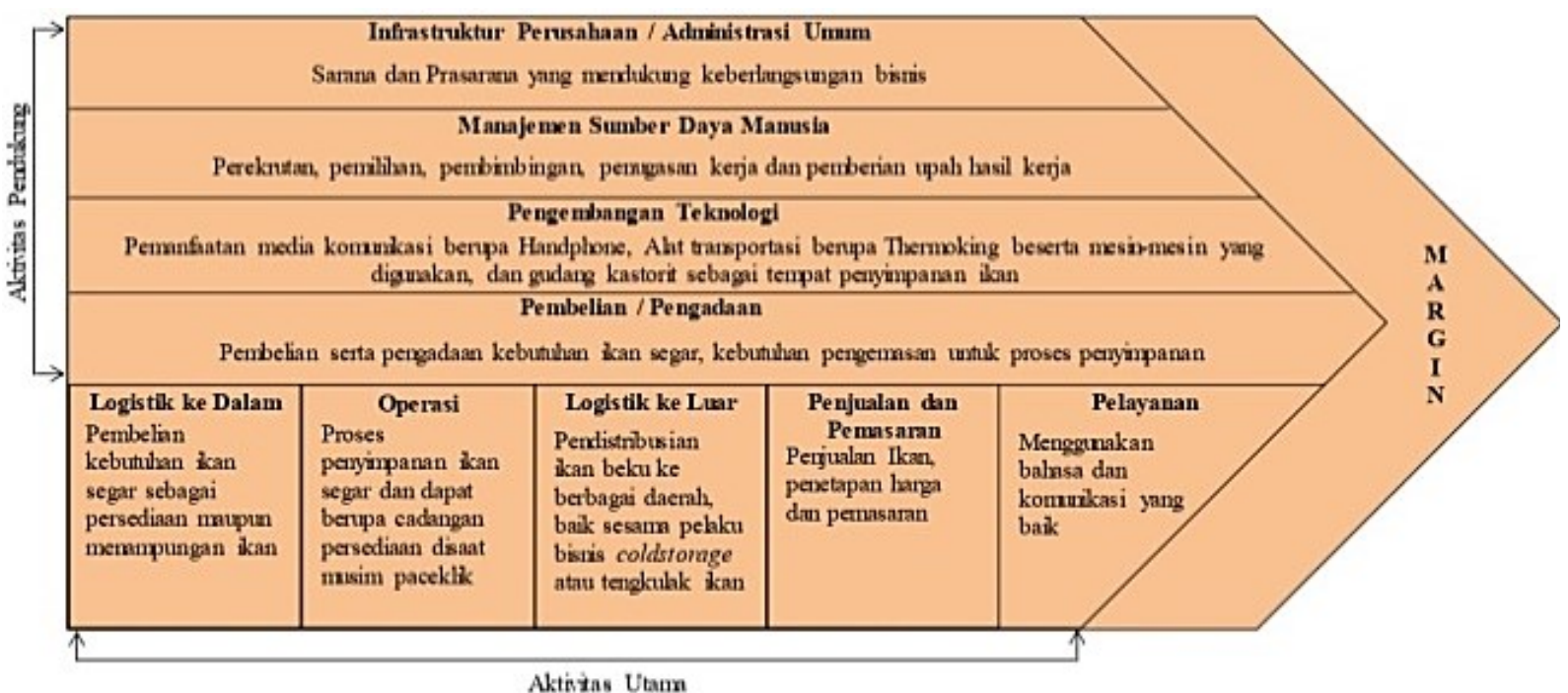

Gambar 4. Aktivitas Rantai Nilai Gudang Ikan menurut Porter (1985) 


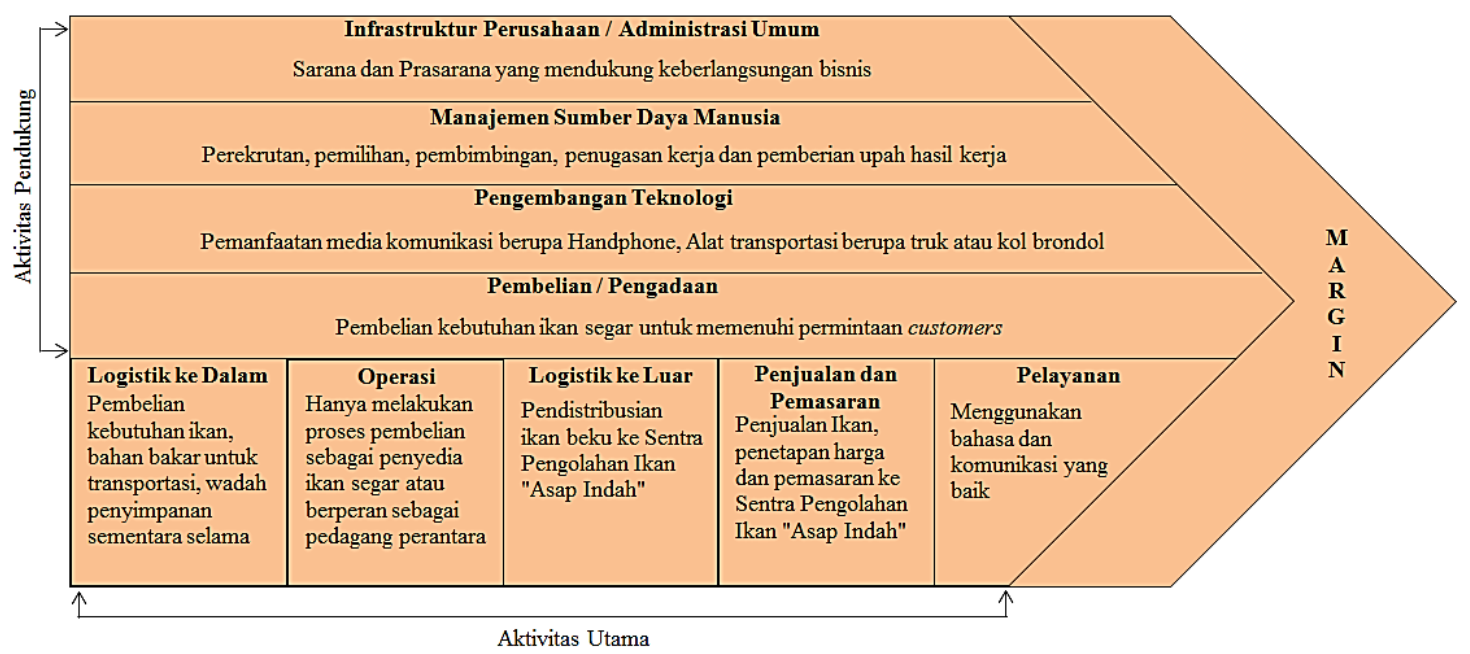

Gambar 5. Aktivitas Rantai Nilai Tengkulak Ikan Segar menurut Porter (1985)

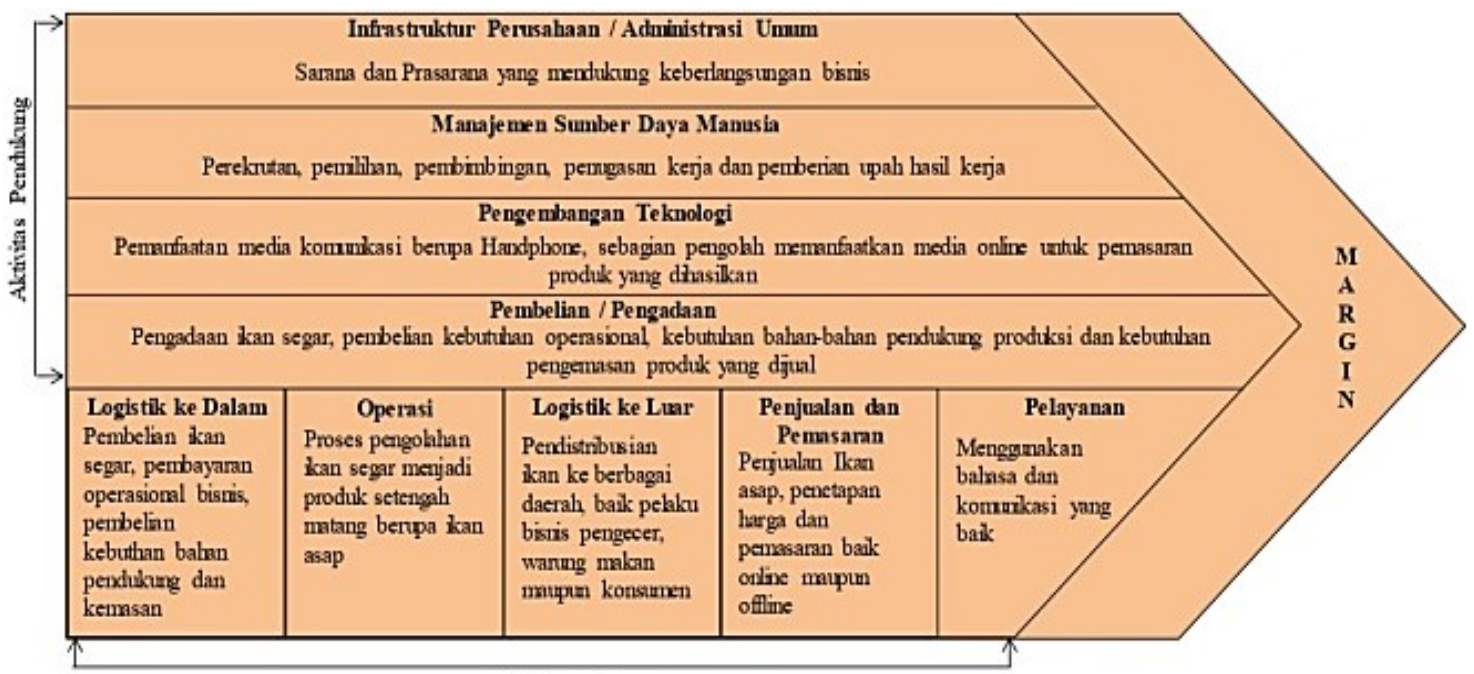

Aktritas Utama

Gambar 6. Aktivitas Rantai Nilai Pengolah Ikan Asap menurut Porter (1985)

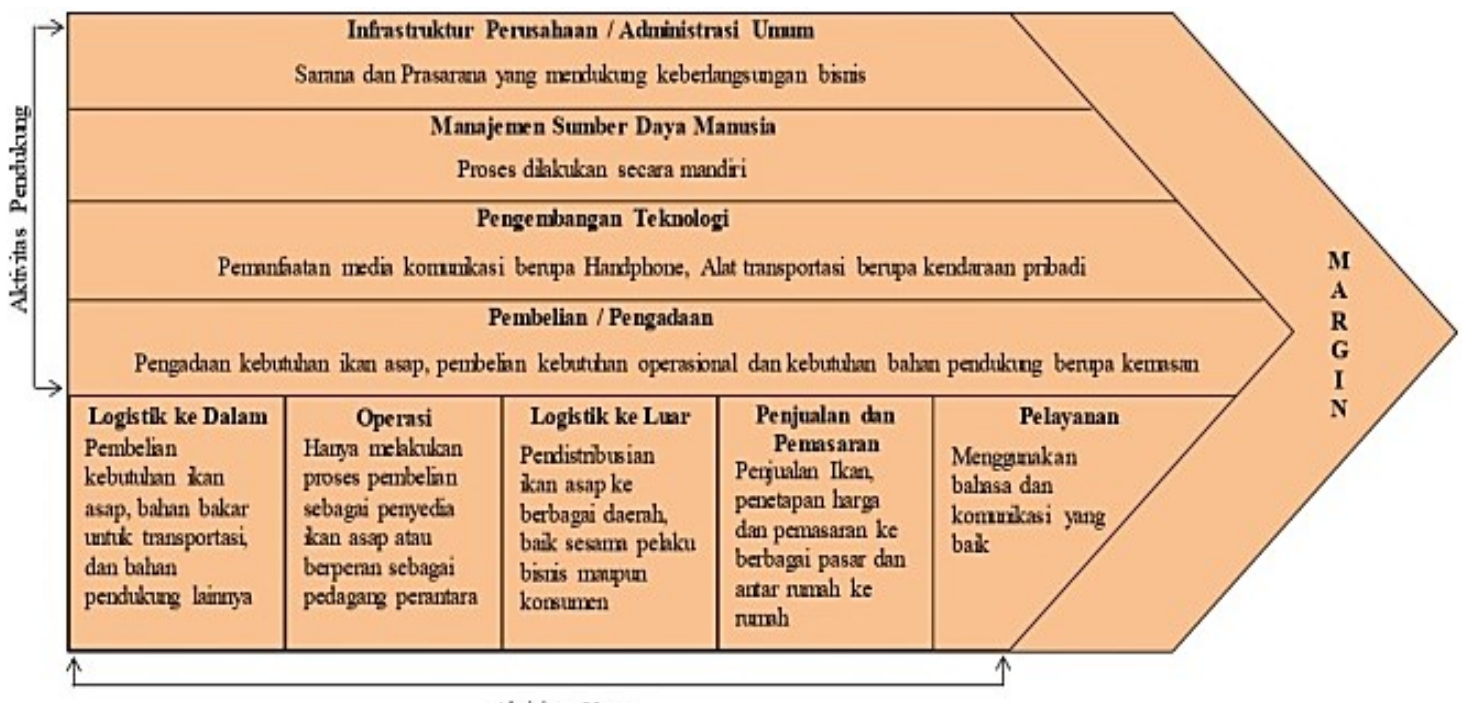

Altrintas Utama

Gambar 7. Aktivitas Rantai Nilai Pengecer Ikan Asap menurut Porter (1985) 


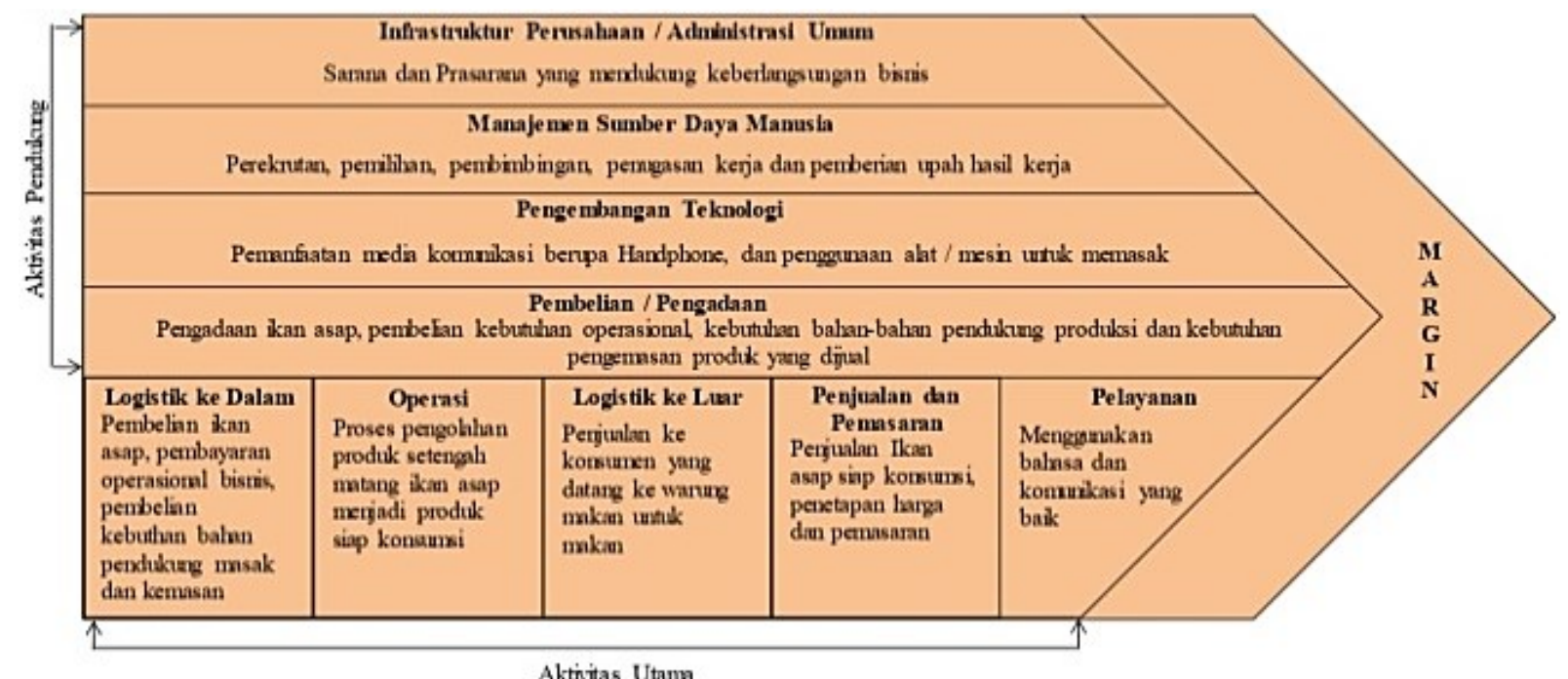

Gambar 8. Aktivitas Rantai Nilai Warung Makan menurut Porter (1985)

\section{Warung Makan}

Gambar 8 merupakan gambaran model aktivitas rantai nilai menurut Porter (1985) pada pelaku usaha di Warung Makan.

\subsection{Analisis Nilai Tambah (Value Added)}

Nilai tambah adalah nilai dari suatu komoditas yang mengalami perlakuan dan dapat menciptakan adanya value added yang terjadi baik pada proses produksi, pengangkutan maupun pada penyimpanan setelah proses produksi (Irawati, 2021). Perhitungan nilai tambah yang dihitung merupakan nilai tambah yang diperoleh dari masing-masing pelaku usaha rantai nilai yang terlibat dalam ikan asap manyung di Sentra Pengolahan Ikan "Asap Indah". Perhitungan yang digunakan dalam menentukan value added adalah menggunakan Metode Hayami.

\section{TPI Unit 1 Juwana}

Hasil perhitungan nilai tambah pada pelaku usaha TPI Unit 1 Juwana dapat dilihat pada tabel 8.

\section{Gudang Ikan}

Hasil perhitungan nilai tambah pada pelaku usaha Gudang Ikan dapat dilihat pada tabel 9.

3. Tengkulak Ikan Segar

Hasil perhitungan nilai tambah pada pelaku usaha Tengkulak Ikan Segar dapat dilihat pada tabel 10.

\section{Pengolah Ikan Asap}

Hasil perhitungan nilai tambah pada pelaku usaha Pengolah Ikan Asap dapat dilihat pada tabel 11.

\section{Pengecer Ikan Asap}

Hasil perhitungan nilai tambah pada pelaku usaha Pengecer Ikan Asap dapat dilihat pada tabel 12.

\section{Warung Makan}

Hasil perhitungan nilai tambah pada pelaku usaha Warung Makan dapat dilihat pada tabel 13.

Setelah dilakukan perhitungan nilai tambah (value added) pada tiap masing-masing pelaku usaha dalam rantai pasok ikan asap manyung yang terlibat, maka diperoleh hasil kesimpulan yang dapat dilihat pada tabel 14. Tabel 14

Tabel 8. Perhitungan Nilai Tambah TPI Unit 1

\begin{tabular}{clrr}
\hline Output, Input dan Harga & Perhitungan \\
\hline 1 & Output (buah/tahun) & 15000 \\
2 & Bahan Baku (Buah/tahun) & 15000 \\
3 & Tenaga Kerja (HOK) & 1500 \\
4 & Faktor Konversi (1/2) & & 1 \\
5 & Koefisien Tenaga Kerja (3/2) & 0,1 \\
6 & Harga Produk (Rp./Kg.) & $\mathrm{Rp}$ & 13.000 \\
7 & Upah rata-rata Tenaga Kerja (Rp./HOK) & $\mathrm{Rp}$ & 12.500 \\
Pendapatan dan Keuntungan & & \\
8 & Harga Bahan Baku (Rp./Buah) & $\mathrm{Rp}$ & 2.568 \\
9 & Sumbangan Input Lain (Rp./Buah) & $\mathrm{Rp}$ & 71 \\
10 & Nilai Produk (Rp./Kg.) (4x6) & $\mathrm{Rp}$ & 13.000 \\
11 & a. Nilai Tambah (Rp./Buah) (10-8-9) & $\mathrm{Rp}$ & 10.361 \\
& b. Rasio Nilai Tambah (\%) (11a/10)x100\% & & $80 \%$ \\
12 & a. Imbalan Tenaga Kerja (Rp./Buah) (5x7) & $\mathrm{Rp}$ & 1.250 \\
& b. Bagian Tenaga Kerja (\%) (12a/11a)x100\% & & $12 \%$ \\
13 & a. Keuntungan (Rp./Buah) (11a-12a) & $\mathrm{Rp}$ & 9.111 \\
& b. Tingkat Keuntungan (\%) (13a/11a)x100\% & & $70 \%$ \\
\hline
\end{tabular}


Tabel 9. Perhitungan Nilai Tambah Gudang Ikan

\begin{tabular}{rlrr}
\hline Output, Input dan Harga & \multicolumn{2}{c}{ Perhitungan } \\
\hline 1 & Output (buah/tahun) & 10000 \\
2 & Bahan Baku (Buah/tahun) & 10000 \\
3 & Tenaga Kerja (HOK) & & 1,3 \\
4 & Faktor Konversi (1/2) & & 0,000125 \\
5 & Koefisien Tenaga Kerja (3/2) & $\mathrm{Rp}$ & 17.000 \\
6 & Harga Produk (Rp./Kg.) & $\mathrm{Rp}$ & 280.000 \\
7 & Upah rata-rata Tenaga Kerja (Rp./HOK) & & \\
Pendapatan dan Keuntungan & $\mathrm{Rp}$ & 13.000 \\
8 & Harga Bahan Baku (Rp./Buah) & $\mathrm{Rp}$ & 1.305 \\
9 & Sumbangan Input Lain (Rp./Buah) & $\mathrm{Rp}$ & 17.000 \\
10 & Nilai Produk (Rp./Kg.) (4x6) & $\mathrm{Rp}$ & 2.695 \\
11 & a. Nilai Tambah (Rp./Buah) (10-8-9) & & $16 \%$ \\
& b. Rasio Nilai Tambah (\%) (11a/10)x100\% & & 35 \\
12 & a. Imbalan Tenaga Kerja (Rp./Buah) (5x7) & $\mathrm{Rp}$ & $1 \%$ \\
& b. Bagian Tenaga Kerja (\%) (12a/11a)x100\% & & 2.660 \\
13 & a. Keuntungan (Rp./Buah) (11a-12a) & $\mathrm{Rp}$ & $16 \%$
\end{tabular}

Tabel 10. Perhitungan Nilai Tambah Tengkulak Ikan

\begin{tabular}{|c|c|c|c|}
\hline \multicolumn{4}{|c|}{ Segar } \\
\hline \multicolumn{2}{|c|}{ Output, Input dan Harga } & \multicolumn{2}{|c|}{ Perhitungan } \\
\hline 1 & Output (buah/tahun) & & 4000 \\
\hline 2 & Bahan Baku (Buah/tahun) & & 4000 \\
\hline 3 & Tenaga Kerja (HOK) & & 3,1 \\
\hline 4 & Faktor Konversi $(1 / 2)$ & & 1 \\
\hline 5 & Koefisien Tenaga Kerja (3/2) & & 0078125 \\
\hline 6 & Harga Produk (Rp./Kg.) & $\mathrm{Rp}$ & 19.500 \\
\hline 7 & Upah rata-rata Tenaga Kerja (Rp./HOK) & $\mathrm{Rp}$ & 128.000 \\
\hline \multicolumn{4}{|c|}{ Pendapatan dan Keuntungan } \\
\hline 8 & Harga Bahan Baku (Rp./Buah) & $\mathrm{Rp}$ & 17.000 \\
\hline 9 & Sumbangan Input Lain (Rp./Buah) & $\mathrm{Rp}$ & 917 \\
\hline \multirow{2}{*}{$\begin{array}{l}10 \\
11\end{array}$} & Nilai Produk (Rp./Kg.) (4x6) & $\mathrm{Rp}$ & 19.500 \\
\hline & a. Nilai Tambah (Rp./Buah) (10-8-9) & $\mathrm{Rp}$ & 1.583 \\
\hline \multirow{2}{*}{12} & b. Rasio Nilai Tambah (\%) (11a/10)x100\% & & $8 \%$ \\
\hline & a. Imbalan Tenaga Kerja (Rp./Buah) $(5 \times 7)$ & $\mathrm{Rp}$ & 100 \\
\hline \multirow{3}{*}{13} & b. Bagian Tenaga Kerja (\%) (12a/11a)x100\% & & $6 \%$ \\
\hline & a. Keuntungan (Rp./Buah) (11a-12a) & $\mathrm{Rp}$ & 1.483 \\
\hline & b. Tingkat Keuntungan (\%) (13a/11a)x100\% & & $8 \%$ \\
\hline
\end{tabular}

merupakan tabel nilai tambah yang diperoleh masing-masing pelaku usaha yang terlibat.

Dari hasil tabel 14, maka dapat ditarik kesimpulan bahwa pelaku usaha yang memberikan hasil nilai tambah (value added) terkecil atau paling sedikit kegiatannya dan mampu memperoleh keuntungan yang besar
Tabel 11. Perhitungan Nilai Tambah Pengolah Ikan Asap

\begin{tabular}{|c|c|c|c|c|c|}
\hline \multirow{2}{*}{\multicolumn{2}{|c|}{ Output, Input dan Harga }} & \multirow{2}{*}{\multicolumn{2}{|c|}{$\begin{array}{l}\text { Perhitungan } \\
\text { Kepala }\end{array}$}} & \multicolumn{2}{|c|}{ Perhitungan } \\
\hline & & & & \multicolumn{2}{|c|}{ Daging } \\
\hline 1 & Output (buah/tahun) & & 138 & & 96 \\
\hline 2 & Bahan Baku (Buah/tahun) & & 138 & & 96 \\
\hline 3 & Tenaga Kerja (HOK) & & 4,5 & & 4,5 \\
\hline 4 & Faktor Konversi $(1 / 2)$ & & 1 & & 1 \\
\hline 5 & $\begin{array}{l}\text { Koefisien Tenaga Kerja } \\
(3 / 2)\end{array}$ & & 2608696 & & 0,047 \\
\hline 6 & $\begin{array}{l}\text { Harga Produk (Rp./Kg.) } \\
\text { Upah rata-rata Tenaga }\end{array}$ & $\mathrm{Rp}$ & 28.333 & $\mathrm{Rp}$ & 58.333 \\
\hline 7 & Kerja (Rp./HOK) & $\mathrm{Rp}$ & 111.111 & $\mathrm{Rp}$ & 111.111 \\
\hline \multicolumn{6}{|c|}{ Pendapatan dan Keuntungan } \\
\hline 8 & $\begin{array}{l}\text { (Rp./Buah) } \\
\text { Sumbangan Input Lain }\end{array}$ & $\mathrm{Rp}$ & 19.500 & $\mathrm{Rp}$ & 19.500 \\
\hline 9 & $\begin{array}{l}\text { (Rp./Buah) } \\
\text { Nilai Produk (Rp./Kg.) }\end{array}$ & $\mathrm{Rp}$ & 233,3 & $\mathrm{Rp}$ & 233,3 \\
\hline 10 & $(4 \times 6)$ & $\mathrm{Rp}$ & 28.333 & $\mathrm{Rp}$ & 58.333 \\
\hline 11 & $\begin{array}{l}\text { a. Nilai Tambah } \\
\text { (Rp./Buah) }(10-8-9) \\
\text { b. Rasio Nilai Tambah (\%) }\end{array}$ & $\mathrm{Rp}$ & 8.600 & $\mathrm{Rp}$ & 38.600 \\
\hline 12 & $\begin{array}{l}(11 \mathrm{a} / 10) \times 100 \% \\
\text { a. Imbalan Tenaga Kerja }\end{array}$ & & $30 \%$ & & $66 \%$ \\
\hline 12 & $\begin{array}{l}\text { (Rp./Buah) }(5 \times 7) \\
\text { b. Bagian Tenaga Kerja }\end{array}$ & $\mathrm{Rp}$ & 3.623 & $\mathrm{Rp}$ & 5.208 \\
\hline 13 & $\begin{array}{l}(\%)(12 a / 11 a) \times 100 \% \\
\text { a. Keuntungan (Rp./Buah) }\end{array}$ & & $42 \%$ & & $1349 \%$ \\
\hline & $\begin{array}{l}(11 \mathrm{a}-12 \mathrm{a}) \\
\text { b. Tingkat Keuntungan }\end{array}$ & $\mathrm{Rp}$ & 4.977 & $\mathrm{Rp}$ & 33.392 \\
\hline & $(\%)(13 a / 11 a) \times 100 \%$ & & $18 \%$ & & $57 \%$ \\
\hline
\end{tabular}

Tabel 12. Perhitungan Nilai Tambah Pengecer Ikan Asap

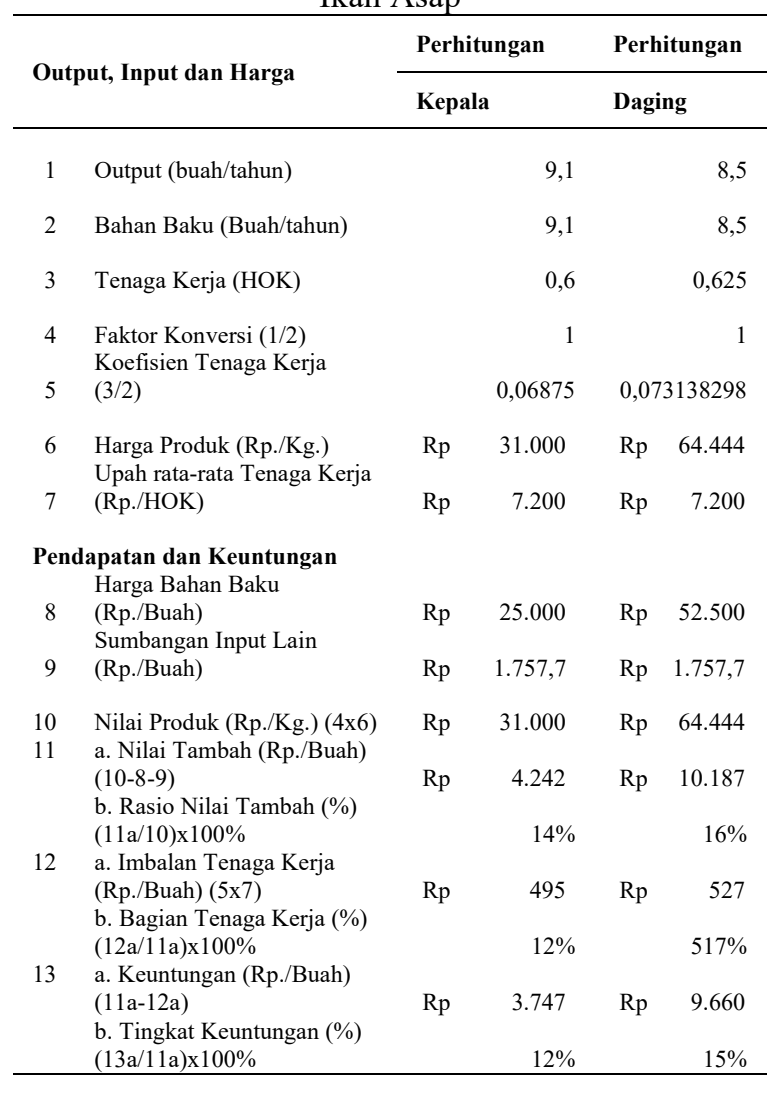


Tabel 13. Perhitungan Nilai Tambah Warung Makan

\begin{tabular}{|c|c|c|c|c|c|}
\hline \multirow{2}{*}{\multicolumn{2}{|c|}{ Output, Input dan Harga }} & \multirow{2}{*}{\multicolumn{2}{|c|}{ Perhitungan }} & \multicolumn{2}{|c|}{ Perhitungan } \\
\hline & & & & \multicolumn{2}{|c|}{ Daging } \\
\hline 1 & Output (buah/tahun) & & 18 & & 1 \\
\hline 2 & Bahan Baku (Buah/tahun) & & 18 & & 1 \\
\hline 3 & Tenaga Kerja (HOK) & & 5,0 & & 1,0 \\
\hline 4 & Faktor Konversi $(1 / 2)$ & & 1 & & 1 \\
\hline 5 & Koefisien Tenaga Kerja (3/2) & & 77777778 & & 1 \\
\hline 6 & Harga Produk (Rp./Kg.) & $\mathrm{Rp}$ & 82.500 & $\mathrm{Rp}$ & 125.000 \\
\hline 7 & $\begin{array}{l}\text { Upah rata-rata Tenaga Kerja } \\
\text { (Rp./HOK) }\end{array}$ & $\mathrm{Rp}$ & 80.000 & $\mathrm{Rp}$ & 60.000 \\
\hline \multicolumn{6}{|c|}{ Pendapatan dan Keuntungan } \\
\hline 8 & Harga Bahan Baku (Rp./Buah) & $\mathrm{Rp}$ & 30.000 & $\mathrm{Rp}$ & 60.000 \\
\hline 9 & $\begin{array}{l}\text { Sumbangan Input Lain } \\
\text { (Rp./Buah) }\end{array}$ & $\mathrm{Rp}$ & 1.579 & $\mathrm{Rp}$ & $1.578,9$ \\
\hline \multirow{3}{*}{$\begin{array}{l}10 \\
11\end{array}$} & Nilai Produk (Rp./Kg.) (4x6) & $\mathrm{Rp}$ & 82.500 & $\mathrm{Rp}$ & 125.000 \\
\hline & $\begin{array}{l}\text { a. Nilai Tambah (Rp./Buah) (10- } \\
8-9)\end{array}$ & $\mathrm{Rp}$ & 50.921 & $\mathrm{Rp}$ & 63.421 \\
\hline & $\begin{array}{l}\text { b. Rasio Nilai Tambah (\%) } \\
(11 \mathrm{a} / 10) \times 100 \%\end{array}$ & & $62 \%$ & & $51 \%$ \\
\hline 12 & $\begin{array}{l}\text { a. Imbalan Tenaga Kerja } \\
\text { (Rp./Buah) }(5 \times 7) \\
\text { b. Bagian Tenaga Kerja (\%) } \\
\text { (12a/11a) } 100 \%\end{array}$ & $\mathrm{Rp}$ & 22.222 & $\mathrm{Rp}$ & 60.000 \\
\hline \multirow[t]{2}{*}{13} & $\begin{array}{l}\text { a. Keuntungan (Rp./Buah) (11a- } \\
\text { 12a) }\end{array}$ & $\mathrm{Rp}$ & 28.699 & $\mathrm{Rp}$ & 3.421 \\
\hline & $\begin{array}{l}\text { b. Tingkat Keuntungan (\%) } \\
\text { (13a/11a)x } 100 \%\end{array}$ & & $35 \%$ & & $3 \%$ \\
\hline
\end{tabular}

adalah pelaku usaha Tengkulak Ikan Segar. Aktivitas dapat dinilai menjadi hal penting dalam pengendalian pengelolaan supply chain yang pastinya tidak dapat dilepaskan dari biaya-biaya yang berkaitan. Menurut Sitorus, dkk (2014) mengatakan bahwa pengelolaan aktivitas merupakan rangkaian tindakan dalam identifikasi aktivitas yang dilakukan oleh suatu perusahaan atau organisasi, menentukan nilai untuk perusahaan, pemilihan dan melakukan kegiatan yang dapat menambah nilai untuk konsumen, melakukan identifikasi atau dengan menghilangkan aktivitas tidak bernilai tambah kemudian memperbaiki aktivitas bernilai tambah sehingga dapat menurunkan biaya (Kutika, 2018). Dengan melakukan pengurangan pada kegiatan yang tidak bernilai tambah, maka tentu saja hal tersebut dapat menurunkan biaya produksi dari Pengolah Ikan Asap di Sentra Pengolahan Ikan “Asap Indah”.

\subsection{Hasil Penelitian}

Dari pembahasan yang dilakukan, maka penelitian ini dapat memberikan usulan bahwa dalam meningkatkan penjualan produk ikan asap manyung di Sentra Pengolahan Ikan "Asap Indah" dan meningkatkan margin yang didapatkan oleh pelaku usaha Pengolah Ikan Asap dapat dengan mengembangkan hasil analisis dari perhitungan rantai nilai dan nilai

Tabel 14. Hasil Nilai Tambah Tiap Pelaku Rantai Pasok

\begin{tabular}{|c|c|c|c|c|c|c|c|c|}
\hline \multirow{2}{*}{$\begin{array}{r}\text { No. } \\
1\end{array}$} & \multirow{2}{*}{$\begin{array}{l}\text { Pelaku Rantai Pasok } \\
\text { TPI Unit } 1\end{array}$} & \multicolumn{2}{|c|}{$\begin{array}{l}\text { Nilai Tambah } \\
\text { (Rp./Kg.) }\end{array}$} & \multirow{2}{*}{$\begin{array}{r}\text { Rasio } \\
\text { Nilai Tambah } \\
80 \%\end{array}$} & \multicolumn{2}{|c|}{$\begin{array}{c}\text { Keuntungan } \\
(\mathrm{Rp} / \mathrm{Kg})\end{array}$} & \multirow{2}{*}{$\begin{array}{r}\begin{array}{c}\text { Rasio } \\
\text { Keuntungan }\end{array} \\
70 \%\end{array}$} & \multirow{2}{*}{$\begin{array}{c}\text { Perbandingan } \\
\begin{array}{c}\text { Nilai Tambah } \\
\text { dengan Keuntungan }\end{array} \\
1,137\end{array}$} \\
\hline & & $\mathrm{Rp}$ & 10.361 & & $\mathrm{Rp}$ & 9.111 & & \\
\hline 2 & Gudang Ikan & $\mathrm{Rp}$ & 2.695 & $16 \%$ & $\mathrm{Rp}$ & 2.660 & $16 \%$ & 1,013 \\
\hline \multirow{3}{*}{$\begin{array}{l}3 \\
4\end{array}$} & Tengkulak Ikan Segar & $\mathrm{Rp}$ & 1.583 & $8 \%$ & $\mathrm{Rp}$ & 1.483 & $8 \%$ & 1,067 \\
\hline & Pengolah Ikan Asap & & & & & & & \\
\hline & Kepala Manyung & $\mathrm{Rp}$ & 8.600 & $30 \%$ & $\mathrm{Rp}$ & 4.977 & $18 \%$ & 1,728 \\
\hline \multirow{3}{*}{5} & Daging Manyung & $\mathrm{Rp}$ & 38.600 & $66 \%$ & $\mathrm{Rp}$ & 33.392 & $57 \%$ & 1,156 \\
\hline & Pengecer Ikan Asap & & & & & & & \\
\hline & Kepala Manyung & $\mathrm{Rp}$ & 4.242 & $14 \%$ & $\mathrm{Rp}$ & 3.747 & $12 \%$ & 1,132 \\
\hline \multirow{4}{*}{6} & Daging Manyung & $\mathrm{Rp}$ & 10.187 & $16 \%$ & $\mathrm{Rp}$ & 9.660 & $15 \%$ & 1,055 \\
\hline & Warung Makan & & & & & & & \\
\hline & Kepala Manyung & $\mathrm{Rp}$ & 50.921 & $62 \%$ & $\mathrm{Rp}$ & 28.699 & $35 \%$ & 1,774 \\
\hline & Daging Manyung & $\mathrm{Rp}$ & 63.421 & $51 \%$ & $\mathrm{Rp}$ & 3.421 & $3 \%$ & 18,538 \\
\hline
\end{tabular}




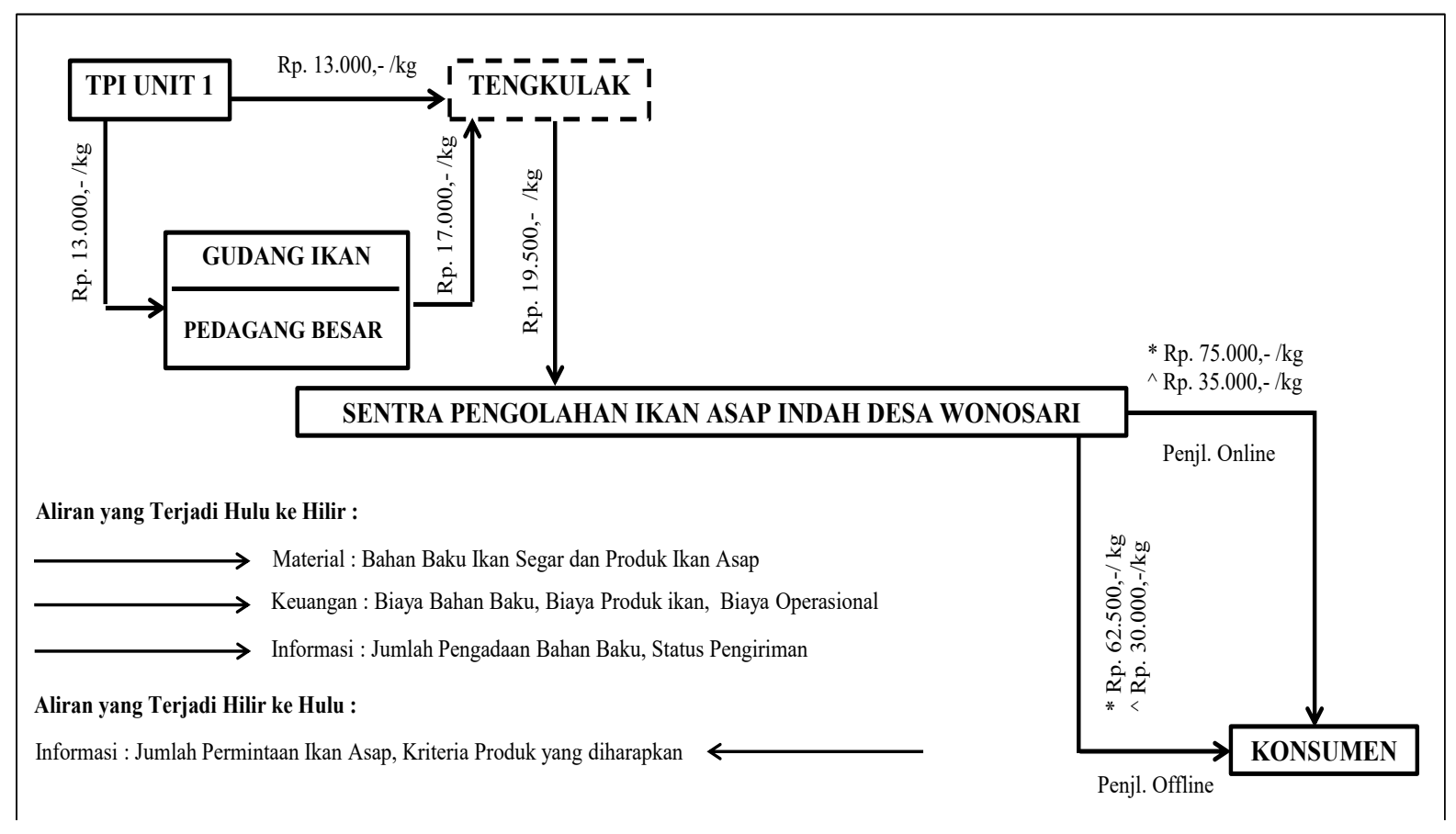

Gambar 9. Saluran Distribusi Usulan Hasil Penelitian

tambah. Gambar 9 merupakan gambar usulan hasil penelitian yang dilakukan.

Pada gambar 9, dapat diperoleh dua hasil dari penelian. Yang pertama adalah berdasarkan hasil analisa rantai nilai (value chain) menunjukkan saluran pendistribusian atau penjualan ikan asap manyung yang paling efisien tertuju langsung ke konsumen akhir karena harga produk ikan asap manyung yang tertinggi adalah penjualan ke konsumen dan oleh karena itu margin yang diperoleh juga akan jauh lebih besar dibanding penjualan ke pelaku usaha yang lain. Namun, pada kondisi sebenarnya akan jauh lebih sulit jika harus melakukan eliminasi pada pelaku usaha yang lain dan akan memberi dampak sosialnya, maka dapat dilakukan dengan tidak menghilangkan 100\% melainkan dengan memainkan proporsi peranya secara bertahap yang berarti memberikan sejumlah sekian presentase produk langsung ditujukan ke konsumen.

Hasil yang kedua adalah berdasarkan hasil analisis pada perhitungan nilai tambah pada tiap pelaku rantai pasok, menunjukkan bahwa pelaku usaha Tengkulak Ikan Segar memberikan hasil nilai tambah terkecil dengan keuntungan yang besar. Dan perannya akan cukup merugikan pada pelaku usaha Pengolah Ikan Asap. Sehingga perlunya dilakukan pengurangan atau meminimalkan proporsi peran dari pelaku usaha
Tengkulak Ikan Segar tersebut dengan cara pihak dari koperasi Sentra Pengolahan Ikan "Asap Indah" melakukan sendiri pembelian dan pengambilan ikan ke supplier pemasok agar dapat meminimalkan biaya produksi ikan asap manyung.

Berdasarkan hasil usulan penelitian juga dapat diketahui mengenai perbandingan hasil nilai tambah sebelum dilakukannya perbaikan dan setelah dilakukan perbaikan yang dapat dilihat pada tabel 15. Pada tabel 15, menunjukkan adanya peningkatan pada nilai tambah yang diberikan dan keuntungan yang diperoleh Pengolah Ikan Asap karena adanya penekanan biaya produksi yang dikeluarkan oleh Pengolah Ikan Asap dengan melakukan pembelian ikan segar langsung ke penyuplai ikan segar tanpa melibatkan Tengkulak Ikan Segar.

Selain itu, dalam meningkatkan penjualan ikan asap manyung dapat diiringi dengan penambahan nilai tambah yang dapat meningkatkan keuntungan yang diperoleh, dapat dilakukan oleh pelaku usaha Pengolah Ikan Asap berupa memberikan atau melakukan pengembangan kemasan vacum agar menambah daya tarik pembeli, selain itu akan membuat produk yang dijual jauh lebih higienis. Terkait dengan kondisi kemasan yang diberikan Pengolah Ikan Asap dapat dilihat pada gambar 10. 
Tabel 15. Perbandingan Nilai Tambah Sebelum dan Sesudah Perbaikan

\begin{tabular}{|c|c|c|c|c|c|c|c|c|c|}
\hline & Output, Input dan Harga & \multicolumn{2}{|c|}{$\begin{array}{c}\text { Kepala } \\
\text { Sebelum } \\
\text { Perbaikan }\end{array}$} & \multicolumn{2}{|c|}{$\begin{array}{c}\text { Kepala } \\
\text { Sesudah } \\
\text { Perbaikan }\end{array}$} & \multicolumn{2}{|c|}{$\begin{array}{c}\text { Daging } \\
\text { Sebelum } \\
\text { Perbaikan } \\
\end{array}$} & \multicolumn{2}{|c|}{$\begin{array}{c}\text { Daging } \\
\text { Sesudah } \\
\text { Perbaikan } \\
\end{array}$} \\
\hline 1 & Output (buah/tahun) & & 138 & & 138 & & 96 & & 96 \\
\hline 2 & Bahan Baku (Buah/tahun) & & 138 & & 138 & & 96 & & 96 \\
\hline 3 & Tenaga Kerja (HOK) & & 4,5 & & 4,5 & & 4,5 & & 4,5 \\
\hline 4 & Faktor Konversi (1/2) & & 1 & & 1 & & 1 & & 1 \\
\hline 5 & Koefisien Tenaga Kerja (3/2) & & 32608696 & & 32608696 & & 0,047 & & 0,046875 \\
\hline 6 & Harga Produk (Rp./Kg.) & $\mathrm{Rp}$ & 28.333 & $\mathrm{Rp}$ & 30.000 & $\mathrm{Rp}$ & 58.333 & $\mathrm{Rp}$ & 62.500 \\
\hline 7 & Upah rata-rata Tenaga Kerja (Rp./HOK) & $\mathrm{Rp}$ & 111.111 & $\mathrm{Rp}$ & 111.111 & $\mathrm{Rp}$ & 111.111 & $\mathrm{Rp}$ & 111.111 \\
\hline \multicolumn{10}{|c|}{ Pendapatan dan Keuntungan } \\
\hline 8 & Harga Bahan Baku (Rp./Buah) & $\mathrm{Rp}$ & 19.500 & $\mathrm{Rp}$ & 17.000 & $\mathrm{Rp}$ & 19.500 & $\mathrm{Rp}$ & 17.000 \\
\hline 9 & Sumbangan Input Lain (Rp./Buah) & $\mathrm{Rp}$ & 233,3 & $\mathrm{Rp}$ & 233,3 & $\mathrm{Rp}$ & 233,3 & $\mathrm{Rp}$ & 233,3 \\
\hline \multirow{2}{*}{$\begin{array}{l}10 \\
11\end{array}$} & Nilai Produk (Rp./Kg.) (4x6) & $\mathrm{Rp}$ & 28.333 & $\mathrm{Rp}$ & 30.000 & $\mathrm{Rp}$ & 58.333 & $\mathrm{Rp}$ & 62.500 \\
\hline & a. Nilai Tambah (Rp./Buah) (10-8-9) & $\mathrm{Rp}$ & 8.600 & $\mathrm{Rp}$ & 12.767 & $\mathrm{Rp}$ & 38.600 & $\mathrm{Rp}$ & $45.266,7$ \\
\hline \multirow{2}{*}{12} & b. Rasio Nilai Tambah (\%) (11a/10)x100\% & & $30 \%$ & & $43 \%$ & & $66 \%$ & & $72 \%$ \\
\hline & a. Imbalan Tenaga Kerja (Rp./Buah) (5x7) & $\mathrm{Rp}$ & 3.623 & $\mathrm{Rp}$ & 3.623 & $\mathrm{Rp}$ & 5.208 & $\mathrm{Rp}$ & 5.208 \\
\hline \multirow{3}{*}{13} & b. Bagian Tenaga Kerja (\%) (12a/11a)x100\% & & $42 \%$ & & $28 \%$ & & $1349 \%$ & & $12 \%$ \\
\hline & a. Keuntungan (Rp./Buah) (11a-12a) & $\mathrm{Rp}$ & 4.977 & $\mathrm{Rp}$ & 9.143 & $\mathrm{Rp}$ & 33.392 & $\mathrm{Rp}$ & $40.058,3$ \\
\hline & b. Tingkat Keuntungan (\%) (13a/11a)x100\% & & $18 \%$ & & $30 \%$ & & $57 \%$ & & $64 \%$ \\
\hline
\end{tabular}

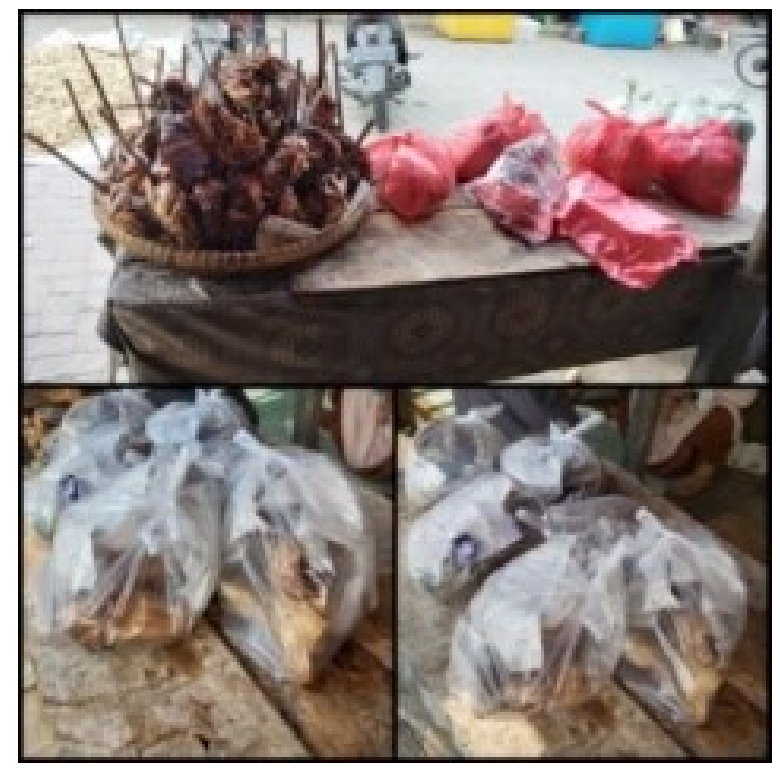

Gambar 10. Kemasan Ikan Asap Manyung Saat Ini

\section{KESIMPULAN}

Berdasarkan analisis dan pembahasan yang telah dilakukan, maka dari hasil tersebut dapat diambil kesimpulan yaitu yang pertama adalah Rantai nilai ikan asap manyung di Sentra Pengolahan Ikan “Asap Indah" dilakukan dengan cara dua analisis yaitu analisis secara kuantitatif dan juga secara kualitatif. Dari hasil analisis kuantitatif diperoleh hasil $>1$ sehingga dapat disimpulkan bahwa semua usaha yang dijalankan tiap pelaku rantai pasok adalah efisien dan menguntungkan. Sedangkan dari hasil analisis kualitatif menggunakan Teori Porter (1985) menunjukkan bahwa semua pelaku usaha dalam rantai pasok ikan asap manyung melaksanakan aktivitas utama dan aktivitas pendukung. Sehingga aktivitas yang dijalankan sudah terorganisir.

Kesimpulan kedua menunjukkan penambahan nilai tambah yang diberikan tiap pelaku rantai nilai ikan asap manyung di Sentra Pengolahan Ikan "Asap Indah diantaranya dimulai dari pemberian nilai tambah terkecil adalah Tengkulak Ikan Segar, Gudang Ikan, Pengecer Ikan Asap, TPI Unit 1, Pengolah Ikan asap dan terbesar adalah Warung Makan.

Kesimpulan ketiga menunjukkan bahwa saluran distribusi ikan asap manyung di Sentra Pengolahan Ikan "Asap Indah" yang paling efisien adalah TPI Unit 1 - Gudang Ikan Tengkulak Ikan Segar - Pengolah Ikan Asap Konsumen.

\section{DAFTAR PUSTAKA}

Arsiwi, P., Adi, P. W., \& Subhiyakto, E. R. (2018). Analisis Value Chain Sebagai Upaya Peningkatan Nilai Produk Ikan Asap 
Bandarharjo. Industrial Engineering Journal of The University of Sarjanawiyata Tamansiswa, 2(1), 35-43.

Azizi, E. S. (2018). Analisis rantai pasok dan nilai tambah komoditas carica di desa patakbanteng kecamatan kejajar kabupaten wonosobo ernes septina azizi.

Estiningtyas, R. A. (2020). TEKNOLOGI INFORMASI UNTUK MENGURANGI WAKTU.

Hariadi, I., Studi, P., Industri, T., Sains, F., Teknologi, D. A. N., Islam, U., ... Kasim, S. (2019). Strategi rantai pasok untuk menentukan nilai tambah produk olahan makanan kulit sapi tugas akhir.

Irawati, S. D. (2021). IDENTIFIKASI DESAIN JARINGAN RANTAI PASOK KENTANG GUNA PENINGKATAN PENDAPATAN PETANI DI KEC. KEJAJAR, KAB. WONOSOBO, JAWA TENGAH.

Ishaq, M., Rumiati, A. T., \& Permatasari, E. O. (2017). Analisis Faktor-Faktor yang Mempengaruhi Produksi Padi di Provinsi Jawa Timur Menggunakan Regresi Semiparametrik Spline. Jurnal Sains Dan Seni ITS, 6(1). https://doi.org/10.12962/j23373520.v6i1.2 2451
Kutika, R. F. (2018). ANALISIS NON VALUE ADDED ACTIVITY MELALUI PENERAPAN ACTIVITY BASED MANAGEMENT UNTUK MENINGKATKAN EFISIENSI PT. INDOFOOD CBP SUKSES MAKMUR, Tbk CABANG BITUNG, 13(2), 402-411.

Nurfadilah, A. P. (2017). ANALISIS RANTAI PASOK DAN RANTAI NILAI PADA JERUK PAMELO SUPPLY. Вестник Росздравнадзора, 4, 9-15.

Nurhuda. (2017). Analisis Manajemen Rantai Pasok Kentang (Solanum Tuberosum L.) di Desa Ngadas, Kecamatan Poncokusumo, Kabupaten Malang. Jurnal Ekonomi Pertanian Dan Agribisnis, 1(2), 130-143. https://doi.org/10.21776/ub.jepa.2017.001. 02.6

Yani, J. A., \& Pos, T. (2015). DI SURAKARTA Liana Mangifera Universitas Muhammadiyah Surakarta Abstract, 19, 24-33. 